\title{
Ligand Dependent Switch from RXR Homo- to RXR-NURR1 Heterodimerization
}

Marcel Scheepstra, ${ }^{\dagger}$ Sebastian A. Andrei, ${ }^{\dagger}$ Rens M. J. M. de Vries, ${ }^{\dagger}$ Femke A. Meijer, $^{\dagger}$ Jian-Nong Ma, $^{\ddagger}$ Ethan S. Burstein, ${ }^{\ddagger}$ Roger Olsson, ${ }^{\S}$ Christian Ottmann, ${ }^{\dagger}$ Lech-Gustav Milroy, ${ }^{*},{ }^{\dagger}$ and Luc Brunsveld ${ }^{*}, \oplus$

${ }^{\dagger}$ Department of Biomedical Engineering and Institute for Complex Molecular Systems, Laboratory of Chemical Biology, Technische Universiteit Eindhoven, Den Dolech 2, 5612 AZ Eindhoven, The Netherlands

${ }^{\ddagger}$ ACADIA Pharmaceuticals Inc., San Diego, California 92130, United States

${ }^{\S}$ Chemical Biology \& Therapeutics, Department of Experimental Medical Science, Lund University, SE-221 00 Lund, Sweden

Supporting Information

ABSTRACT: Retinoid X receptors (RXRs) play key roles in many physiological processes in both the periphery and central nervous system. In addition, RXRs form heterodimers with other nuclear receptors to exert their physiological effects. The nuclear receptor related 1 protein (NURR1) is particularly interesting because of its role in promoting differentiation and survival of dopamine neurons. However, only a small number of RXR-heterodimer selective modulators are available, with limited chemical diversity. This work describes the synthesis, biochemical evaluation, and structural elucidation of a novel series of RXR ligands with strongly biased interactions with

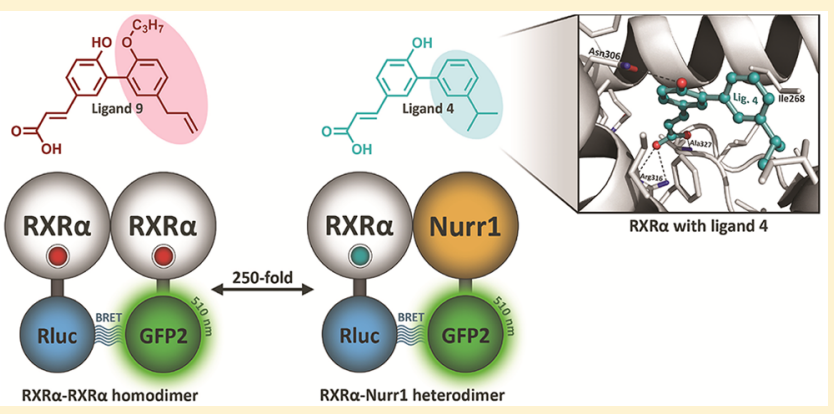
RXR $\alpha$-NURR1 heterodimers. Targeted modifications to the small molecule biaryl scaffold caused local $\operatorname{RXR} \alpha$ side-chain disturbances and displacement of secondary structural elements upon ligand binding. This resulted in the repositioning of protein helices in the heterodimer interface of RXR $\alpha$, alterations in homo- versus heterodimer formation, and modulation of activation function 2 (AF2). The data provide a rationale for the design of RXR ligands consisting of a highly conserved hydrophilic region, strongly contributing to the ligand affinity, and a variable hydrophobic region, which efficiently probes the effects of structural changes at the level of the ligand on co-regulator recruitment or the $\operatorname{RXR} \alpha-\mathrm{NURR} 1$ dimerization interface.

KEYWORDS: Nuclear receptors, heterodimerization, ligand binding domain, retinoid $X$ receptor, nuclear receptor related 1

\section{INTRODUCTION}

The retinoid $\mathrm{X}$ receptor (RXR) plays a key role as a transcriptional regulator through formation of heterodimers with other nuclear receptor partners. Activation of RXR heterodimers exerts neuroprotective effects in animal models of neurodegenerative disorders such as Alzheimer's disease, Parkinson's disease and multiple sclerosis. ${ }^{1-4}$ The activity of RXRs is influenced by a class of compounds related to the naturally occurring 9-cis-13,14-dihydroretinoic acid. ${ }^{5}$ The Lshaped ligand binding pocket is unique to RXRs, and structural information derived from X-ray crystallographic data of the RXR ligand binding domains in the apo or holo state ${ }^{6,7}$ has aided the design of specific ligands for this receptor. ${ }^{8}$ Comprehensive overviews of the structure, biology, and therapeutic implications of targeting RXRs with small molecule ligands are available. ${ }^{8-12}$ However, the chemical diversity of these ligands is limited by the structural constraints placed by the RXR ligand binding pocket and the availability of synthetic methodologies to access designed ligands. ${ }^{13}$ Controlled RXR heterodimerization and RXR partial agonism are contemporary biomedical challenges, ${ }^{11,14}$ both of which could in principle be addressed via exploration of an appropriate structural class.

Three RXR subtypes are known, $\operatorname{RXR} \alpha$ (subject of this study), $\operatorname{RXR} \beta$, and RXR $\gamma$ (NR2B1, NR2B2, and NR2B3), and all three interact similarly with many coregulator proteins, and with several nuclear receptors to form heterodimers. Ligand binding to RXR can induce the transcriptional activity of some of its heterodimeric partner receptors (NURR1, NGFIB, FXR, LXR, CAR, and PPAR). ${ }^{15}$ Thus, RXR-selective ligands that only activate specific RXR heterodimers may have greater therapeutic potential, because they would be expected to cause fewer side effects compared to ligands that cause general activation of RXR-NR heterodimers. ${ }^{5,9,11}$ In this respect, RXR-PPAR and RXR-LXR heterodimers have gained a lot of attention, as the clearance of $\mathrm{A} \beta$ through apoE in Alzheimer's mouse models is believed to be facilitated by the activation of these heterodimers. ${ }^{16,17}$ For example, the ligand LG101506 was

Received: June 12, 2017

Accepted: July 10, 2017

Published: July 10, 2017 


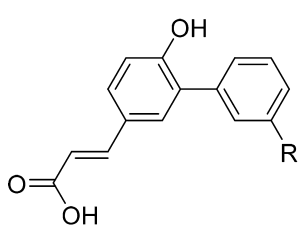

1: $\mathrm{R}=\mathrm{CH}_{2} \mathrm{CH}=\mathrm{CH}_{2}$

2: $\mathrm{R}=\mathrm{Ph}$

3: $\mathrm{R}=\mathrm{Bn}$

4: $\mathrm{R}=\mathrm{iPr}$

5: $\mathrm{R}=\mathrm{nPr}$

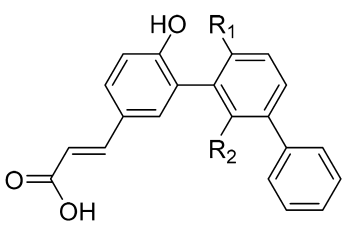

6: $\mathrm{R}_{1}=\mathrm{H}, \mathrm{R}_{2}=\mathrm{CH}_{3}$

7: $\mathrm{R}_{1}=\mathrm{CH}_{3}, \mathrm{R}_{2}=\mathrm{H}$

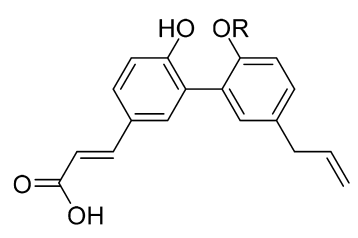

8: $\mathrm{R}=\mathrm{H}$

9: $\mathrm{R}=n-\mathrm{C}_{3} \mathrm{H}_{7}$

10: $\mathrm{R}=n-\mathrm{C}_{6} \mathrm{H}_{13}$

Figure 1. Designed biaryl-based RXR ligands 1-10 and established potent RXR agonist LG100268.

identified as the most potent of a series of selective RXRPPAR heterodimer activators, ${ }^{18,19}$ whereas it did not activate the RXR-LXR heterodimer. The potential of this selective RXR modulator as a treatment for type 2 diabetes with reduced side effects was shown in mice. Activation of RXR-nuclear receptor heterodimers with RXR receptor ligands also provides an important strategy for activating orphan nuclear receptors which themselves do not readily bind ligands (e.g., NURR1).

The nuclear receptor related 1 protein or NURR1 (also referred to as NR4A2) controls the development, function, and survival of dopaminergic neurons. ${ }^{20-22}$ NURR1 knockout mice have reduced dopaminergic neurons and show perinatal lethality. ${ }^{23,24}$ Loss of function NURR1 genetic polymorphisms in patients are linked to familial Parkinson's disease. ${ }^{25,26}$ The crystal structure of the LBD of NURR1 reveals a "closed" ligand binding pocket, with the C-terminal helix 12 in a canonical fold analogous to agonist bound ligand binding domains ${ }^{27}$ which may not easily allow access to small molecule ligands. ${ }^{28}$ Therefore, modulation of NURR1 activity via RXRs would constitute a viable entry point for NURR1 activitation. ${ }^{4,29-31}$ A limited number of RXR-NURR1 heterodimer activators have been reported with promising selectivity over other RXR-heterodimer pairs. ${ }^{4,32,33}$ Notwithstanding these important advances in developing selective RXR-heterodimer modulators, there is a demand for a broader portfolio of RXRNURR1 modulators, both for use as research tools, to address open question such as regarding the resulting effect on RXR signaling via other heterodimers and the potential presence of physiological ligands with similar profiles, and as potential drugs. ${ }^{22}$

Here we report the synthesis, biophysical evaluation and structural elucidation of a new series of RXR $\alpha$ ligands with a strong bias toward promoting RXR $\alpha-$ NURR1 heterodimer versus $\mathrm{RXR} \alpha-\mathrm{RXR} \alpha$ homodimer formation. The work makes use of the knowledge derived from studies on the natural product $^{34}$ honokiol derived RXR $\alpha$ agonists described previously. ${ }^{35}$ The biaryl scaffold of this series is straightforward to derivatize, which in principle enables a rapid pharmacophore mapping of the RXR $\alpha$ ligand binding pocket. In this present study, ligands 1-5 (Figure 1) were designed to probe the hydrophobic region of the RXR $\alpha$ ligand binding pocket, while keeping the polar interactions intact, to access the flexibility and local displacements of amino acid side-chains of the ligand binding domain. Ortho-substituted ligands 6 and 7 were synthesized to investigate how constraining the conformation of the biaryl system would affect the activity of these ligands. Finally, a canonical side-chain extension ${ }^{36}$ of the biaryl scaffold in the direction of the RXR $\alpha$ helix 12 produced compounds 9 and 10, for the purpose to investigate for possible RXR $\alpha$ partial and full antagonism. This compact set of chemical probes was subsequently evaluated as RXR $\alpha$ ligands, using a fluorescencebased polarization assay and cellular mammalian two-hybrid assay. In addition, their effectiveness in modulating RXR $\alpha-$ NURR1 heterodimers over $\mathrm{RXR} \alpha-\mathrm{RXR} \alpha$ homodimers was tested using cell-based bioluminescence resonance energy transfer (BRET2) assays. ${ }^{2,33}$ To corroborate these results and to elucidate the binding mode and conformational changes in the protein induced by these compounds, the X-ray structures of five of these novel ligands bound to $\mathrm{RXR} \alpha$ were solved.

\section{RESULTS AND DISCUSSION}

Synthesis. The synthesis and cocrystal structure of ligand $\mathbf{1}$ were described previously. ${ }^{35}$ The allyl side chain of 1 partly occupies the lipophilic pocket in the ligand binding domain of $\operatorname{RXR} \alpha$, analogously to the tetramethyl-cyclohexene unit found in typical RXR ligands, leading to closure of the ligand binding pocket via repositioning of helix 12 in an agonist conformation and subsequent increased binding toward coactivators. The high binding affinity and low molecular weight of $\mathbf{1}$ makes it an ideal scaffold to explore modifications targeting the lipophilic pocket (Table 1). Ligands $\mathbf{2}-\mathbf{5}$ were therefore synthesized

Table 1. Summary of Fluorescence Polarization (FP) and Mammalian Two-Hybrid (M2H) Data for the RXR $\alpha$ Agonists $^{a}$

\begin{tabular}{lcc}
\multicolumn{1}{c}{ compd } & $\mathrm{FP} / \mathrm{EC}_{50}(\mathrm{nM})$ & $\begin{array}{c}\mathrm{M} 2 \mathrm{H}(\text { luciferase }) / \mathrm{EC}_{50} \\
(\mathrm{nM})\end{array}$ \\
$\mathrm{LG100268}$ & $150 \pm 40$ & $5.1 \pm 2.0$ \\
$\mathbf{1}\left(\mathrm{R}=\mathrm{CH}_{2} \mathrm{CH}=\mathrm{CH}_{2}\right)$ & $260 \pm 110$ & $6.3 \pm 4.0$ \\
$\mathbf{2}(\mathrm{R}=\mathrm{Ph})$ & $140 \pm 23$ & $85 \pm 9$ \\
$\mathbf{3}(\mathrm{R}=\mathrm{Bn})$ & $142 \pm 9$ & $92 \pm 36$ \\
$\mathbf{4}(\mathrm{R}=i \mathrm{Pr})$ & $89 \pm 7$ & $5.8 \pm 1.8$ \\
$\mathbf{5}(\mathrm{R}=n \mathrm{Pr})$ & $170 \pm 80$ & $18 \pm 10$ \\
$\mathbf{6}$ & $9900 \pm 2500$ & $>2500$ \\
7 & $1020 \pm 60$ & $14600 \pm 1800$
\end{tabular}

${ }^{a}$ EC50 values for LG100268 and ligands 1-7. See experimental section for details of the assays. The 20 - to 30 -fold difference between the $\mathrm{FP}$ and $\mathrm{M} 2 \mathrm{H}$ data for the more potent compounds is a common phenomemon, ${ }^{35,40}$ which can be explained by intrinsic differences between the two different assay formats, in particular, the different protein and peptide concentrations used.

bearing structural variations in the hydrophobic side chain. The synthesis of compounds $2-5$ relied on efficient palladiumcatalyzed cross coupling reactions (Scheme 1). The cinnamic acid derivative 11 was treated with thionyl chloride in methanol to obtain the methyl cinnamate derivative 12. Four boronic acids or esters were then reacted with 12 using Suzuki coupling 
Scheme 1. Synthesis of Novel Biaryl RXR $\alpha$ Ligands $^{a}$<smiles>COc1ccc(/C=C/C(=O)O)cc1Cl</smiles>

11<smiles>COC(=O)/C=C/c1ccc(OC)c(Cl)c1</smiles>

12

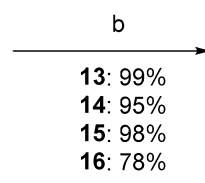

6: $78 \%$

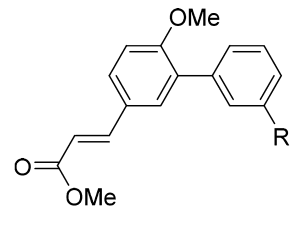

13: $\mathrm{R}=\mathrm{Ph}$

14: $R=B n$

15: $\mathrm{R}=i-\mathrm{Pr}$

16: $\mathrm{R}=n-\mathrm{Pr}$

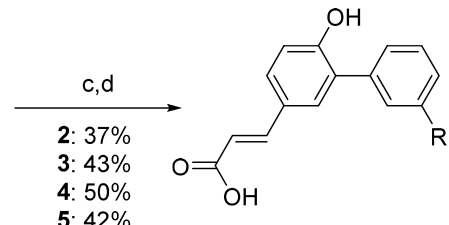

2: $\mathrm{R}=\mathrm{Ph}$

3: $\mathrm{R}=\mathrm{Bn}$

4: $\mathrm{R}=i-\mathrm{Pr}$

5: $\mathrm{R}=n-\mathrm{Pr}$

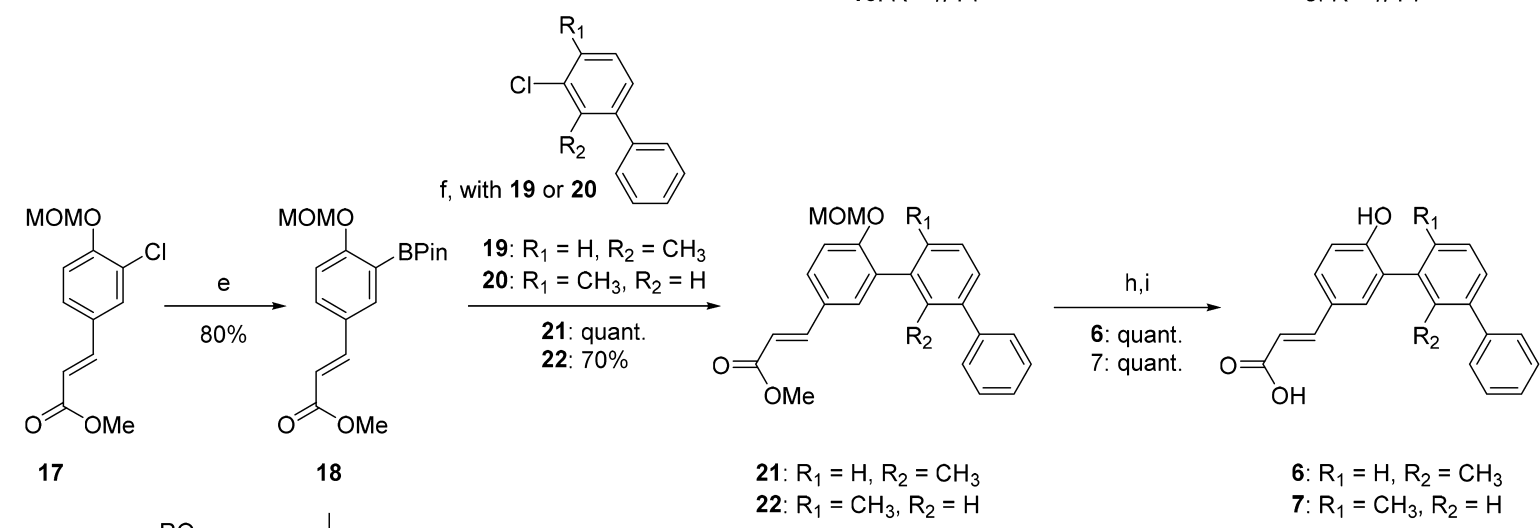

23: $\mathrm{R}=n-\mathrm{C}_{3} \mathrm{H}_{7}$

24: $\mathrm{R}=n-\mathrm{C}_{6} \mathrm{H}_{13}$

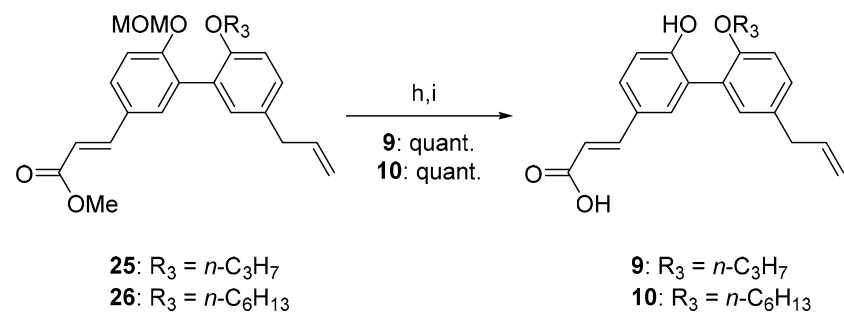

${ }^{a_{T}}$ The syntheses of $\mathbf{1}$ and $\mathbf{8}$ have been previously reported. ${ }^{35}$ Conditions: (a) thionyl chloride, $\mathrm{MeOH}, 0{ }^{\circ} \mathrm{C}$; (b) arylboronic acid or arylboronic ester, $\mathrm{Pd}_{2}(\mathrm{dba})_{3}$, SPhos, $\mathrm{KF}$, dioxane $/ \mathrm{H}_{2} \mathrm{O}(10: 1 \mathrm{v} / \mathrm{v}), 110{ }^{\circ} \mathrm{C}$; (c) $\mathrm{BBr}_{3}, \mathrm{CH}_{2} \mathrm{Cl}_{2}-78{ }^{\circ} \mathrm{C}$; (d) $\mathrm{NaOH}$, dioxane/MeOH $(14: 5 \mathrm{v} / \mathrm{v}), 40{ }^{\circ} \mathrm{C}$; $(\mathrm{e})$ bis(pinacolato)diboron, $\mathrm{Pd}(\mathrm{OAc})_{2}$, XPhos, KOAc, dioxane $110^{\circ} \mathrm{C}$; (f) 19 or $20, \mathrm{Pd}_{2}(\mathrm{dba})_{3}$, SPhos, $\mathrm{KF}$, dioxane/ $\mathrm{H}_{2} \mathrm{O}(6: 1 \mathrm{v} / \mathrm{v}), 110{ }^{\circ} \mathrm{C}$; $(\mathrm{g}) 23$ or 24, $\mathrm{Pd}_{2}(\mathrm{dba})_{3}$, SPhos, $\mathrm{KF}$, dioxane $/ \mathrm{H}_{2} \mathrm{O}(6: 1 \mathrm{v} / \mathrm{v}), 110{ }^{\circ} \mathrm{C}$; (h) $\mathrm{HCl}$, THF, room temperature; (i) $\mathrm{NaOH}$, dioxane/MeOH $(14: 5 \mathrm{v} / \mathrm{v})$.

(Buchwald-modified) to provide intermediates $13-16$ in excellent yields (78-99\%). ${ }^{35,37}$ The biaryls 13-16 were thereafter demethylated using boron tribromide and hydrolyzed using sodium hydroxide, yielding ligands $\mathbf{2 - 5}$ in reasonable yields with high purities after a preparative HPLC purification. Molecules 6 and 7 were designed and synthesized to access the contorted conformation necessary for the biaryl ligands to fit within the ligand binding pocket of $\operatorname{RXR} \alpha{ }^{8}$ To enable a more efficient synthesis, the methyl protection of the phenol (11) was replaced by a methoxymethyl acetal (MOM) group (17). Subsequent Miyaura borylation enabled the key palladium cross coupling with 19 or 20 , accessible in a single step in moderate yields $(51-57 \%)$. The biaryl products were then treated with dilute hydrochloric acid (3 M) to deprotect the phenol in quantitative yields. Finally, the methyl ester was efficiently hydrolyzed using sodium hydroxide, yielding ligands 6 and 7 .

In our efforts to selectively drive $\operatorname{RXR} \alpha$ homodimers, and not RXR $\alpha$-NURR1 heterodimers, toward an antagonistic conformation, we applied the previously validated strategy by
Nahoum and co-workers for inducing RXR antagonism. ${ }^{36}$ Compound 8 (Figure 1) was previously described by us and found to lack significant $\operatorname{RXR} \alpha$ activity, because of the additional polar phenolic functionality, which points toward a lipophilic environment. ${ }^{35}$ X-ray crystallographic data have demonstrated that alkylation of the appropriate phenol displaces the position of helix 12 toward a (partial) antagonistic fold, influencing the position of L436, which plays a determining role in the communication with helix 12. . $^{36,38}$ Therefore, using the biaryl scaffold, agonist $\mathbf{8}$ was modified with two different length alkoxy chains. The length of the alkoxy chain was hypothesized to be directly correlated with the displacement of helix 12 and therefore its antagonist properties. $^{36}$ The antagonists 9 and $\mathbf{1 0}$ were synthesized using intermediate $\mathbf{1 8}$ for the Suzuki couplings, using the ligands introduced by Buchwald, ${ }^{35,37}$ with either 23 or 24 . Intermediates $\mathbf{2 3}$ and $\mathbf{2 4}$ were each made in two steps in excellent yields via $\mathrm{sp}^{2}-\mathrm{sp}^{3} \mathrm{Pd}$-catalyzed cross couplings on the bromide group to introduce the allyl-substituted group. Finally, 
Table 2. Pharmacological Evaluation of Hetero- and Homodimerization Using BRET2 Assays ${ }^{a}$

\begin{tabular}{|c|c|c|c|c|c|}
\hline \multirow[t]{2}{*}{ compd } & \multicolumn{2}{|c|}{ RXR $\alpha-N U R R 1$} & \multicolumn{2}{|c|}{$\mathrm{RXR} \alpha-\operatorname{RXR} \alpha$} & \multirow{2}{*}{$\frac{\text { NURR } 1-\mathrm{RXR} \alpha \text { vs } \mathrm{RXR} \alpha-\mathrm{RXR} \alpha \text { selectivity }}{\text { fold }}$} \\
\hline & $\mathrm{pEC}_{50}(\mathrm{SD})$ & $\%$ Eff (SD) & $\mathrm{pEC}_{50}(\mathrm{SD})$ & $\% \mathrm{Eff}(\mathrm{SD})$ & \\
\hline LG100268 & $9.3(0.3)$ & $100(7)$ & $8.2(0.2)$ & $100(11)$ & 13 \\
\hline 1 & $8.6(0.2)$ & $129(14)$ & $7.5(0.1)$ & $269(32)$ & 13 \\
\hline 2 & $8.5(0.2)$ & $148(15)$ & $7.5(0.1)$ & $283(15)$ & 10 \\
\hline 3 & $8.6(0.2)$ & $178(18)$ & $7.7(0.1)$ & $286(44)$ & 8 \\
\hline 4 & $9.1(0.4)$ & $129(4)$ & $7.7(0.1)$ & $291(28)$ & 25 \\
\hline 5 & $8.3(0.2)$ & $141(9)$ & $7.0(0.0)$ & $286(37)$ & 20 \\
\hline 6 & $6.1(0.2)$ & $330(38)$ & $6.8(0.2)$ & $236(11)$ & 0.2 \\
\hline 7 & $7.1(0.4)$ & $123(12)$ & $7.5(0.1)$ & $175(24)$ & 0.4 \\
\hline 9 & $6.8(0.2)$ & $41(25)$ & $7.7(0.2)$ & $66(6)$ & 0.1 \\
\hline 10 & $<5.0$ & $32(19)$ & $<5.0$ & $42(18)$ & \\
\hline
\end{tabular}

${ }^{a}$ The BRET2 assay was performed as described previously. ${ }^{33,41}$

intermediates $\mathbf{2 5}$ and $\mathbf{2 6}$ were treated with hydrochloric acid in THF for the deprotection of the MOM-group and subsequently with sodium hydroxide for the hydrolysis of the methyl ester to provide the antagonists 9 and $\mathbf{1 0}$.

Pharmacological Evaluation. The activity of the ligands on $\operatorname{RXR} \alpha$ was initially profiled using a fluorescence-based coactivator recruitment polarization (FP) assay and then in a more biologically relevant mammalian two-hybrid (M2H) assay. The FP and $\mathrm{M} 2 \mathrm{H}$ assays revealed an $\mathrm{EC}_{50(\mathrm{FP})}=260$ $\mathrm{nM}$ and $\mathrm{EC}_{50(\mathrm{M} 2 \mathrm{H})}=6.3 \mathrm{nM}$ for 1 , which compares favorably to the established, but more bulky, full agonist LG100268: $\mathrm{EC}_{50(\mathrm{FP})}=150 \mathrm{nM}$ and $\mathrm{EC}_{50(\mathrm{M} 2 \mathrm{H})}=5.1 \mathrm{nM}$ (Table 1). The differences in measured $\mathrm{EC}_{50}$ affinities between the $\mathrm{FP}$ assay and the $\mathrm{M} 2 \mathrm{H}$ assay are a common phenomenon because of intrinsic differences between the two assay formats, the protein concentrations, and the coregulator peptide. ${ }^{35,39}$ Besides 1, ligands $\mathbf{2 - 5}$ also displayed full agonism in both assays with the measured affinities $\left(\mathrm{EC}_{50}\right)$ in the nanomolar range (Table 1$)$. Replacing the allyl group with the closely related $i$-propyl (4) or $n$-propyl (5) did not strongly affect the ligand affinity for RXR $\alpha$. The aromatic phenyl (2) and benzyl (3) substituents displayed a 10-fold decrease in potency in the $\mathrm{M} 2 \mathrm{H}$ cell-based assay compared to the smaller propyl substituents. Nevertheless, also these ligands still activate $\operatorname{RXR} \alpha$ with nanomolar potencies. The RXR $\alpha$ binding of $\mathbf{1 - 5}$ is thus dominated by the hydrophilic portion of the biaryl ligands, i.e., the hydroxylcinnamic acid moiety. The hydrophobic substituents tune the ligand affinity but are not crucial for high ligand affinity. As such, ligand modifications at this part of the molecule could provide an entry to affect the homo- vs heterodimer preference of $\operatorname{RXR} \alpha$.

The terphenyl ligand 2, provides an interesting platform to study the importance and effects of the rotation around the two phenyl-phenyl bonds. Addition of a single methyl group at the central phenyl ( 6 and 7) was thought to direct the rotation to preferred orientations in complex with $\operatorname{RXR} \alpha$. Ligands 6 and 7 both displayed full agonism in the FP assay and the $\mathrm{M} 2 \mathrm{H}$ assay, albeit with potencies in the $1-10 \mu \mathrm{M}$ range (Table 1 ). Comparison with the nanomolar affinities observed for ligand 2, demonstrates that the addition of the single methyl groups strongly impacts affinity for $\operatorname{RXR} \alpha$. This very strict SAR is typical for this class of biphenyls, as in our previous studies the placement of a hydroxyl functionality, such as in $\mathbf{8}$, similarly impacted affinity by changes over $100-$ fold. $^{35}$ In the case of 6 and 7 , the decrease in affinity might be caused by a suboptimal conformational match of the ligand for binding to the protein in the conformation befitting the binding pocket (vide infra).
We previously studied ligand $\mathbf{8}$, which demonstrated full agonism, but with only moderate affinity for $\mathrm{RXR} \alpha$ in FP as well as M2H assays. ${ }^{35}$ The design of $\mathbf{9}$ and $\mathbf{1 0}$ prompted us to study these compounds in a competition format to profile their antagonist characteristics. RXR $\alpha$ was therefore stimulated with the full agonist LG100268 and the subsequent impact of ligands 9 and $\mathbf{1 0}$ on coregulator recruitment was studied via fluorescence polarization studies and on transcription via $\mathrm{M} 2 \mathrm{H}$ assays. The addition of ligands $\mathbf{9}$ or $\mathbf{1 0}$ to the agoniststimulated $\operatorname{RXR} \alpha$ resulted in decreased fluorescence polarization, indicating lowered coactivator recruitment via displacement of the agonist and stabilization of an inactive $\mathrm{RXR} \alpha$ conformation. Ligand $\mathbf{1 0}$ demonstrated full antagonism, while ligand 9 showed partial antagonism (Figure 3a). Consistent with its partial antagonist activity, ligand 9 also displayed partial agonism in an agonist assay format. The measured affinities of 9 $\left(\mathrm{IC}_{50(\mathrm{FP})}=48.5 \pm 4.6 \mu \mathrm{M}\right)$ and $10\left(\mathrm{IC}_{50(\mathrm{FP})}=46.9 \pm 5.9 \mu \mathrm{M}\right)$ at the $\operatorname{RXR} \alpha$ receptor were approximately 25 -fold lower than that of the known antagonist UVI3003: $\mathrm{IC}_{50(\mathrm{FP})}=1.8 \pm 0.6$ $\mu \mathrm{M}$. Compounds 9 and 10 were also $\operatorname{RXR} \alpha$ antagonists in the cell-based $\mathrm{M} 2 \mathrm{H}$ assay. $\mathrm{M} 2 \mathrm{H}$ competition experiments showed a clear decrease in luciferase expression upon addition of either ligand in the $10-40 \mu \mathrm{M}$ range after stimulation with agonist LG100268 (Figure 3b).

The potency and efficacy of the biaryl ligands to induce $\mathrm{RXR} \alpha-\mathrm{RXR} \alpha$ homodimer and $\mathrm{RXR} \alpha-$ NURR1 heterodimer conformational changes was determined using cellular BRET2 assays $^{2,33}$ (Table 2). Agonist ligands $\mathbf{1 - 5}$ all displayed remarkably strong potencies (single digit and sub-nanomolar $\mathrm{EC}_{50}$ 's) and high efficacies, comparable to the chemically optimized agonist LG100268 (Figure 1). Ligands 1-5 all feature preferential affinity for RXR $\alpha-N U R R 1$ heterodimers. Ligand 4 displayed an encouraging 25-fold higher potency at $\operatorname{RXR} \alpha-\mathrm{NURR} 1$ over $\operatorname{RXR} \alpha-\mathrm{RXR} \alpha$, with a $\mathrm{pEC}_{50}$ of 9.1. It should be noted that in these same assays both the well-studied RXR ligand bexarotene and the recently developed dihydrobenzofuran-based ligands only showed $2-7$-fold selectivity. ${ }^{2,33}$ In contrast, the methylated terphenyl ligands 6 and 7 showed higher potency at $\operatorname{RXR} \alpha-\operatorname{RXR} \alpha$ homodimers. The addition of the single methyl group to 2 ortho to the biphenyl bonds, resulting in 6 and 7, thus leads to a reversal in homo- vs heterodimer affinity.

The potency and efficacy of the antagonistic biaryl ligands 9 and 10 to selectively induce $\operatorname{RXR} \alpha-\operatorname{RXR} \alpha$ homodimers over RXR $\alpha$-NURR1 heterodimers toward antagonistic conformational changes was also determined. Partial antagonist 9 shows a profile similar to 6 and 7, but with further biased interactions 

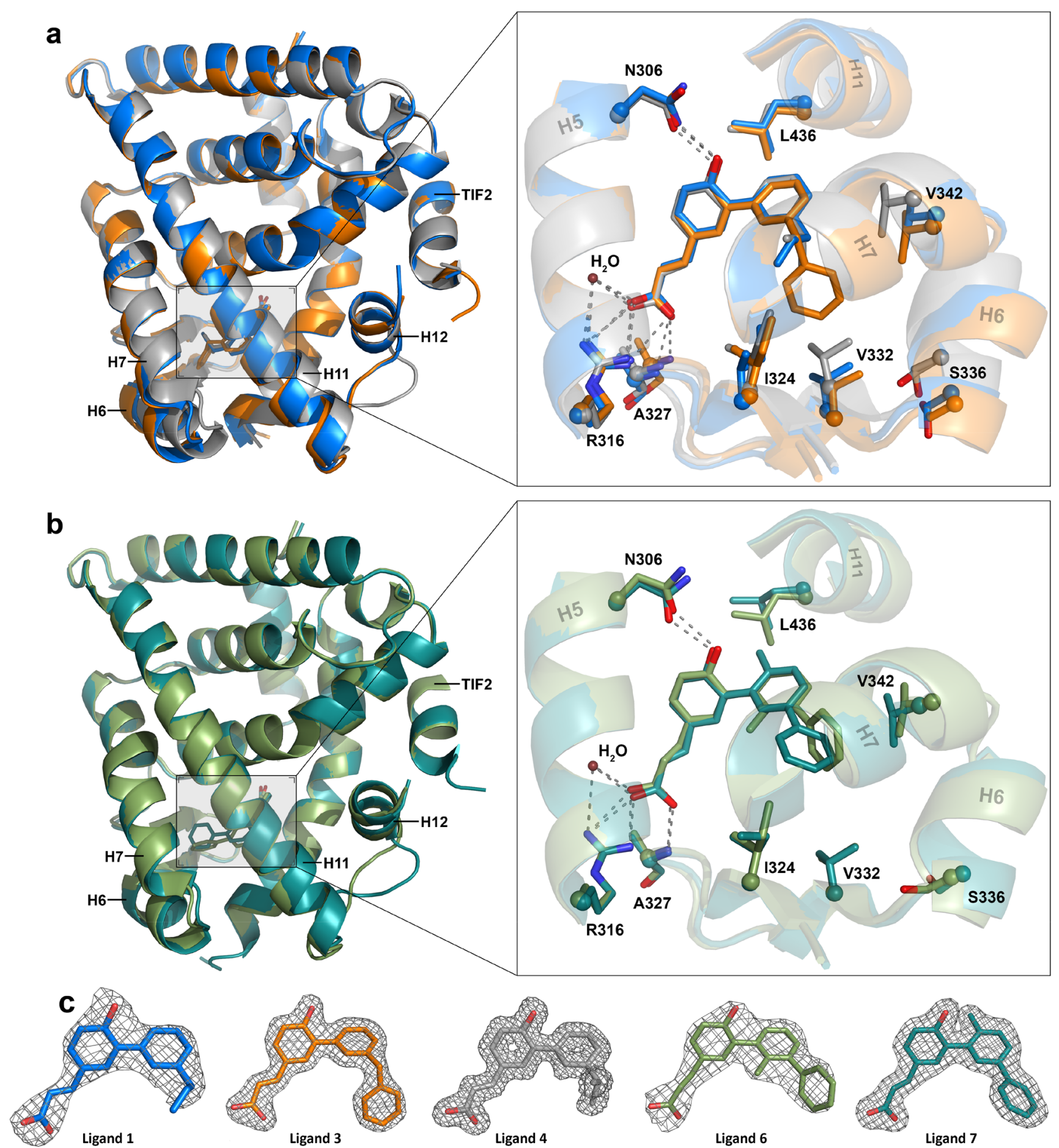

Figure 2. Crystal structures of RXR $\alpha$ with agonists 1, 3, 4, 6, and 7. (a) Overlay of the X-ray cocrystal structures of ligands 1 (blue, PDB: 4OC7), 3 (orange, PDB: 5MJ5, $1.9 \AA$ resolution), and 4 (gray, PDB: 5MKU, $1.8 \AA$ resolution) bound in the ligand binding pocket of RXR $\alpha$ in ribbon representation with the TIF2 derived coregulator peptide. Zoom-in on the ligand binding pocket of RXR $\alpha$ with the amino acids represented as sticks showing the interactions and displacements. (b) Overlay of the X-ray cocrystal structures of ligands 6 (light green, PDB: 5MMW, $2.7 \AA$ resolution) and 7 (dark green, PDB: 5MK4, 2.0 Å resolution) bound to the ligand binding pocket of RXR $\alpha$ in ribbon representation with the TIF2 derived coregulator peptide. Zoom-in on the ligand binding pocket of RXR with the amino acid represented as sticks showing the interactions between the ligands and the protein. (c) Final $2 \mathrm{~F}_{\mathrm{o}}-\mathrm{F}_{\mathrm{c}}$ electron density maps (contoured at $1 \sigma$ ) of ligands 1, 3, 4, 6, and 7.

toward RXR $\alpha$ homodimers over RXR $\alpha$-NURR1 heterodimers by a factor of 10 . Additionally, ligand 9 featured a lower efficacy consistent with its partial antagonist character. The full antagonist 10 did not show appreciable activity in the BRET2 assays.
Structural Evaluation. The cocrystallization of ligands 1, 3, and 4 with $\operatorname{RXR} \alpha$ showed the canonical interactions of the carboxylate group of the ligands with Arg316, the backbone nitrogen of Ala327, and a conserved water molecule (Figure 2a). The free hydroxyl group on the ligands makes a hydrogen bond with Asn306. This hydrogen bonding network is 

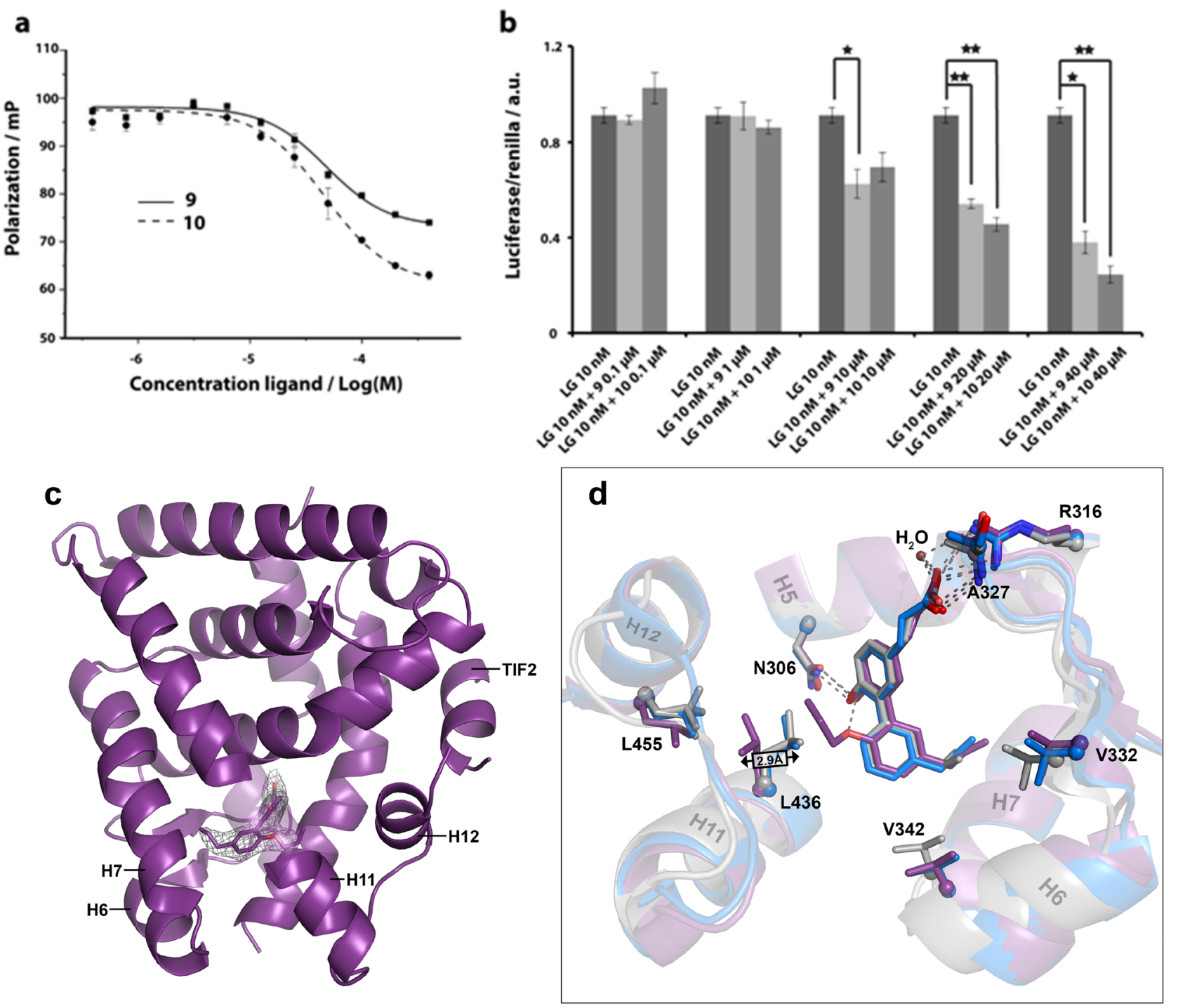

Figure 3. Ligands 9 and 10 are antagonists at RXR $\alpha$. (a) Fluorescence polarization data showing antagonist activity for 9 and 10 . Ligand 9 displays partial antagonism, while $\mathbf{1 0}$ acts as a full antagonist in a competition assay against LG100268 (50 nM). (b) Cellular antagonist activities of 9 and 10 measured in an M2H luciferase competition assay against LG100268 (10 nM). (c) X-ray cocrystal structures of ligand 9 (purple, PDB: 5MKJ, $2.5 \AA$ resolution) bound in the ligand binding pocket of RXR $\alpha$ in ribbon representation with the TIF2 derived coregulator peptide. Ligand 9 is shown with final $2 \mathrm{~F}_{\mathrm{o}}-\mathrm{F}_{\mathrm{c}}$ electron density maps (contoured at $1 \sigma$ ). Note that part of RXR $\alpha$ helix 11 is omitted to allow visualization of the ligand. (d) Zoom-in on an overlay of the ligand binding pockets of RXR $\alpha$ cocrystallized with ligands 1 (blue), 4 (gray), and 9 (purple). Relevant helices and amino acids and their displacements are shown. Compared to 4, ligand 1 induces an outward expansion of helices 6 and 7. Next to this, ligand 9 induces an additional outward displacement of leucines 436 and 455 on helices 11 and 12 .

conserved for all the ligands and directs the positioning of the hydrophobic part of the molecules. The hydrophobic component of 1,3 , and 4 occupies the lipophilic region of the ligand binding pocket. In this region, ligand-dependent $\operatorname{RXR} \alpha$ amino acid reorientations can be observed. Especially ligand 4 (i-propyl substitution) repositions Ile324, Val332, Ser336, and Val342 compared to ligands 1 and 3, creating a smaller ligand binding pocket (Figure 2a, zoom and Supporting Information Figure S60). This tighter packing of helices is less pronounced for the region around Ile 324, but mostly affects helices 6 and 7, showing amino acid displacements up to $2.8 \AA$, and the end of $\operatorname{RXR} \alpha$ helix 11, and with that the loop between helix 11 and 12. The carboxy-terminal part of helix 11 has been identified to play a pivotal role in the dimerization of RXRs, $^{42-44}$ such as via polar contacts between the C-terminal carboxylic acid of PPAR Helix 12 and lysine 431 of RXR helix
$10 / 11 .{ }^{45}$ NURR1 features an atypical, longer, helix $12^{27}$ which, following a modeled RXR-NURR1 heterodimer ${ }^{46}$ and published RXR-PPAR crystal structures, ${ }^{45,47}$ probably points toward the $\operatorname{RXR} \alpha$ LBD, notably $\operatorname{RXR} \alpha$ helices 7 and 11 . RXR $\alpha$-NURR1 heterodimerization thus implies repositioning of $\operatorname{RXR} \alpha$ structural elements in this region to accommodate binding of the NURR1 helix 12. Ligand 4 shows the strongest bias toward RXR $\alpha-$ NURR1 heterodimerization (Table 2). The repositioning of $\operatorname{RXR} \alpha$ helices 7 and 11 by the compact ligand structure might therefore explain its strong selectivity for heterodimerization.

Terphenyl ligands 6 and 7 were provided with a methyl functionality at the ortho-position at either of the two biphenyl bonds. Compared to nonmethylated 2, ligands 6 and 7 featured decreased affinity for $\operatorname{RXR} \alpha$ and bias toward $\operatorname{RXR} \alpha-\operatorname{RXR} \alpha$ homodimerization. The X-ray cocrystallization of ligands 6 and 
7 with $\operatorname{RXR} \alpha$ showed the canonical NR fold, bound to a coregulator peptide (Figure $2 \mathrm{~b}$ ). The biphenyl core scaffold of 6 and 7 was more out-of-plane rotated in comparison to the other agonists. Ligands 6 and 7 fit the canonical L-shaped ligand binding pocket via the same hydrogen bonding network, but compared to, for example, ligand $\mathbf{4}$ induce significant changes in the positioning of several amino acids and helices 6,7 , and 11 and their connecting loops, which form the lipophilic region of the binding pocket (Figure 2b). More specifically, compared to ligand 4, the side chain residues of Val332, Ser336 and Val342 are displaced by 1.0 to $2.2 \AA$ when either ligand 6 or 7 are bound (Figures S60-S62). The ortho-methyl substituent on ligand 6 causes the phenyl ring to rotate more out of plane than the other ligands due to steric clash between the methyl and phenyl groups (Figure S61). This specific out-of-plane orientation of the third phenyl group is apparently unfavorable for the binding of ligand 6 as illustrated by the 10 -fold lower $\operatorname{RXR} \alpha$ activity compared to 7 (Table 1 ). The additional orthomethyl substituent on ligand 7 points into the direction of helix 11, displacing Leu436 (Figure S61). This steric interaction is unfavorable in the context of the phenyl substitution pattern, as highlighted by the strong drop in RXR $\alpha$ activity of 7 compared to ligand 2. Combined, the methyl substituents on 6 and 7 result in both cases in repositioning of $\operatorname{RXR} \alpha$ structural elements, which may correlate with a lower bias toward RXR $\alpha-N U R R 1$ heterodimerization as observed in the BRET2 assay.

To gain structural information about the effects of the additional alkoxy group of $\mathbf{9}$ and 10, the X-ray structure of the RXR $\alpha$ ligand binding domain complexed with ligand 9 and the co-regulator peptide TIF2 was solved. The protein was crystallized in the agonist conformation, stabilized by interactions with the coregulator peptide, and reflected the partial (ant)agonist character of $\mathbf{9}$. Comparison of this structure with that of agonist $\mathbf{1}$ and its analogs (vide supra) revealed, as expected, ${ }^{36}$ reorientations of amino acid residues related to helix 12 positioning (Figure $3 \mathrm{c}, \mathrm{d}$ ). The most dominant reorientation affected Leu436 in helix 11 induced by the $n$ propoxy chain, which rotated around 3.0 A toward helix 12, notably L455. Leu436 has been described as a key residue for the communication between the ligand and helix 12 and the correlated activation function-2 (AF2). ${ }^{9,36,48}$ The repulsive interaction between the L436 and L455 will lower the association strength between helix 12 and the ligand binding domain, shifting the equilibrium of conformations of the receptor in solution toward an antagonist conformation as demonstrated by the FP and $\mathrm{M} 2 \mathrm{H}$ data (Figure 3a,b). The effect might be proportional to the chain length and provides a reasonable rationale for the full antagonism of ligand $\mathbf{1 0}$.

The position of the biaryl scaffold of 9 in the $\operatorname{RXR} \alpha$ ligand binding pocket is shifted compared to full agonists like $\mathbf{1}$ and $\mathbf{4}$ (Figure 3d). This results in concomitant shifts of RXR $\alpha$ helices 6 and 7, especially when compared to ligand 4 and analogous to ligands 6 and 7. Similar to ligand 7, the double substitution pattern on the biaryl scaffold allows partial agonist 9 to simultaneously address two parts of the ligand binding pocket, via helices 6 and 7 and via helices 11 and 12. The combined addressing of the different parts of the $\operatorname{RXR} \alpha$ pocket via the hydrophobic substitution pattern leads to amino acid shifts that correlate with preferential affinity for $\operatorname{RXR} \alpha-\operatorname{RXR} \alpha$ homodimers (Table 2).

\section{CONCLUSIONS}

Despite the fact that RXR receptors play major roles in many biological processes through heterodimerization with other nuclear receptors, only a small number of small molecule RXRheterodimer selective modulators are available, with limited chemical diversity and biophysical properties. This study has delivered a compact and focused selection of RXR $\alpha-N U R R 1$ agonists based on a versatile biaryl scaffold, structurally different than previously reported molecules. ${ }^{10}$ In earlier work using chiral dihydrobenzofuran acids, we demonstrated a 3-fold biased interaction with RXR $\alpha$-NURR $1 .{ }^{33}$ The biaryl scaffold presented here provides a 25-fold selectivity bias for $\operatorname{RXR} \alpha-$ NURR1 in the case of analogue 4, and a $>100$-fold switch in homo- vs heterodimer selectivity when comparing analogs 4 and 9 in Table 2. The structural elucidation of five of these novel $\operatorname{RXR} \alpha$ ligands, in our view, provides a first rationale toward understanding how to generate $\mathrm{RXR} \alpha-\mathrm{NURR} 1$ heterodimer selective ligands. Key ligand-protein interactions and correlated side-chain displacements were identified, modulating both selective dimerization and coregulator recruitment. Interactions of the ligand with key amino acid chains such as Ile324, Val332, Ser336, and Val342 on helices 6 and 7 tune the size of the ligand binding pocket. These compact ligands bind $\operatorname{RXR} \alpha$ in a manner that allows movement of helix 7 and 11 to generate a compact ligand binding pocket conformation which arguable is more suited for heterodimerization with NURR1, potentially by enabling the accommodation of the long NURR1 helix 12. Interactions of substituents on the biaryl scaffold with $\operatorname{RXR} \alpha$ amino acids involved in formation of the AF2, such as Leu436, induce helix 12 repositioning and translate into lower ligand affinities or, alternatively, into (partial) antagonist properties. These interactions with helices 11 and 12 are matched by the expansion of the RXR $\alpha$ ligand binding pocket via helices 6 and 7, leading to a selectivity of the biaryl scaffold for $\operatorname{RXR} \alpha-\operatorname{RXR} \alpha$ heterodimers.

This novel series of ligands allows addressing a wide range of $\operatorname{RXR} \alpha$ receptor conformations and associated functional outcomes via substitution patterns on the same biaryl scaffold, expanding the current RXR modulator repertoire with agonist as well as antagonist ligands. The data provide a rationale for the design of RXR ligands comprised of a unique hydrophilic region with a conserved hydrogen bonding network contributing to the binding affinity, and a hydrophobic region to probe the other parts of the receptor influencing dimerization properties or coregulator recruitment. These findings justify further exploration of the ligand-controlled homo- vs heterodimerization of RXR and its interaction partners, for activation of the NURR1:RXR $\alpha$ heterodimer as monotherapy for Parkinson's disease, ${ }^{2,4}$ for delineating the resulting physiological effects on other RXR heterodimers, and also for potentially revealing conserved mechanisms for other nuclear receptors.

\section{METHODS}

Synthesis. All the solvents employed were commercially available and used without purification unless stated otherwise. Water was purified using a Millipore purification train. All the reagents are commercially available and used without purification. All the NMR data were recorded on a Varian Gemini $400 \mathrm{MHz}$ NMR, a Bruker Cryomagnet $400 \mathrm{MHz}$, a Bruker UltraShield Magnet $400 \mathrm{MHz}$, or a Varian $200 \mathrm{MHz}$ (400 or $200 \mathrm{MHz}$ for ${ }^{1} \mathrm{H}$ NMR and 100 or $50 \mathrm{MHz}$ for ${ }^{13} \mathrm{C}$ NMR). Proton experiments are reported in parts per million 
(ppm) downfield of TMS. All ${ }^{13} \mathrm{C}$ spectra were reported in ppm relative to residual chloroform (77 $\mathrm{ppm})$. Analytical LC-MS was performed on a C4, Jupiter SuC4300A, $150 \times 2.00 \mathrm{~mm}$ column with a gradient $5 \%-100 \%$ acetonitrile in $\mathrm{H}_{2} \mathrm{O}$ supplemented with $0.1 \% \mathrm{v} / \mathrm{v}$ formic acid (FA) in $15 \mathrm{~min}$. Silica column chromatography was performed manually using silica with particle size $60-200 \mu \mathrm{m}$. Preparative HP-LC was performed on a Gemini S4 110A $150 \times 21.20$ mm column using $\mathrm{H}_{2} \mathrm{O}$ and acetonitrile supplemented with $0.1 \% \mathrm{v} / \mathrm{v}$ F.A. Purity and exact mass of the compounds were determined using a High Resolution LC-MS system consisting of a Waters ACQUITY UPLC I-Class system coupled to a Xevo G2 quadrupole time of flight (Q-tof) system. The system comprised a Binary Solvent Manager and a Sample Manager with Fixed-Loop (SM-FL). compounds were separated $\left(0.3 \mathrm{~mL} \mathrm{~min}^{-1}\right)$ by the column (Polaris C18A reverse phase column $2.0 \times 100 \mathrm{~mm}$, Agilent) using a $15 \%-75 \%$ acetonitrile gradient in water supplemented with $0.1 \% \mathrm{v} / \mathrm{v}$ FA before analysis in positive mode in the mass spectrometer. On the basis of LC-UV data, all final compounds are $\geq 95 \%$ pure.

General Procedure for Suzuki Couplings Method A for the Synthesis of Compounds 13-16, 21, 22, 25, and 26. An oven-dried Schlenk tube was charged with aryl halide (1.0 equiv), boronic acid or boronic ester ( 1.2 equiv), KF ( 5.0 equiv), SPhos ( 0.30 equiv), and $\mathrm{Pd}_{2}(\mathrm{dba})_{3}$ (0.010 equiv). The Schlenk tube was evacuated and backfilled with argon three times. Degassed dioxane $/ \mathrm{H}_{2} \mathrm{O}(10: 1 \mathrm{v} / \mathrm{v}$, final aryl halide concentration $0.2 \mathrm{M}$ ) was added under positive argon flow, and the reaction was stirred at the indicated temperature for the indicated time. The reaction mixture was then allowed to cool to room temperature, passed through Celite with ethyl acetate and concentrated in vacuo. The crude product was purified by flash silica gel chromatography using the indicated eluent and concentrated in vacuo.

General Procedure for Suzuki Couplings Method B for the Synthesis of 19 and 20. An oven-dried Schlenk tube was charged with aryl halide (1.0 equiv), boronic acid or boronic ester (2.0 equiv), KOAc (3.0 equiv), and $\mathrm{Pd}(\mathrm{dppf}) \mathrm{Cl}_{2}$ (0.010 equiv). The Schlenk tube was evacuated and backfilled with argon three times. Degassed dioxane $/ \mathrm{H}_{2} \mathrm{O}(5: 1 \mathrm{v} / \mathrm{v}$, final aryl halide concentration $0.4 \mathrm{M})$ was added under positive argon flow, and the reaction was stirred at the indicated temperature for the indicated time. The reaction mixture was then allowed to cool to room temperature and was separated between $\mathrm{CH}_{2} \mathrm{Cl}_{2}$ and $\mathrm{H}_{2} \mathrm{O}$. The aqueous layer was extracted twice with $\mathrm{CH}_{2} \mathrm{Cl}_{2}$. The combined organic layers were washed with brine, dried over $\mathrm{Na}_{2} \mathrm{SO}_{4}$, filtered and concentrated in vacuo. The crude product was purified by flash silica gel chromatography using the indicated eluent and concentrated in vacuo.

General Procedure for Deprotection, Method A: Methyl Ethers and Methyl Esters. The compound was dissolved in dry $\mathrm{CH}_{2} \mathrm{Cl}_{2}$ to a final concentration of $\sim 0.25 \mathrm{M}$ and cooled to $-78{ }^{\circ} \mathrm{C}$. A solution of $\mathrm{BBr}_{3}\left(1 \mathrm{M}\right.$ in $\mathrm{CH}_{2} \mathrm{Cl}_{2}, 2.0$ equiv) was added dropwise, and the reaction was stirred at $-78{ }^{\circ} \mathrm{C}$ for $1 \mathrm{~h}$. The temperature was raised to $0{ }^{\circ} \mathrm{C}$, and the reaction was stirred for another hour. The reaction was then allowed to warm to room temperature and quenched with $\mathrm{H}_{2} \mathrm{O}$. The aqueous layer was extracted with $\mathrm{CH}_{2} \mathrm{Cl}_{2}$ three times, and the combined organic layers washed with brine, dried over $\mathrm{Na}_{2} \mathrm{SO}_{4}$, filtered, and concentrated in vacuo.

The crude product was then dissolved in dioxane/ $\mathrm{MeOH}(14 / 5 \mathrm{v} /$ v) to a concentration of $\sim 0.20 \mathrm{M}$. To this mixture was added $\mathrm{NaOH}$ (4 $\mathrm{N}$ in deionized water, 3.0 equiv), and the resulting mixture was stirred overnight at either room temperature or $40^{\circ} \mathrm{C}$. The solvent was then removed in vacuo, and the residue separated in $\mathrm{H}_{2} \mathrm{O}$ and $\mathrm{CH}_{2} \mathrm{Cl}_{2}$. The aqueous layer was extracted with $\mathrm{CH}_{2} \mathrm{Cl}_{2}$ three times, and the combined organic layers were washed with brine, washed over $\mathrm{Na}_{2} \mathrm{SO}_{4}$, filtered, and evaporated in vacuo. The products were then purified by preparative reversed-phase HPLC by UV detection.

General Procedure for Deprotection, Method B: MOM Ethers and Methyl Esters. The compound was dissolved in THF to a final concentration of $\sim 0.2 \mathrm{M}$. A solution of $\mathrm{HCl}\left(6 \mathrm{~N}\right.$ in $\mathrm{H}_{2} \mathrm{O}, 3.0$ equiv) was added, and the reaction was stirred at room temperature overnight. The reaction was then diluted with $\mathrm{H}_{2} \mathrm{O}$ and extracted with $\mathrm{Et}_{2} \mathrm{O}$ three times. The combined organic layers were washed with saturated aqueous $\mathrm{NaHCO}_{3}$ and brine, dried over $\mathrm{Na}_{2} \mathrm{SO}_{4}$, filtered, and concentrated in vacuo.

The crude product was then dissolved in dioxane/ $\mathrm{MeOH}(14 / 5 \mathrm{v} /$ v) to a concentration of $\sim 0.20 \mathrm{M}$. To this mixture was added $\mathrm{NaOH}$ (4 $\mathrm{N}$ in deionized water, 3.0 equiv), and the resulting mixture was stirred overnight at either room temperature or $40{ }^{\circ} \mathrm{C}$. The solvent was then removed in vacuo, and the residue separated in $\mathrm{H}_{2} \mathrm{O}$ and $\mathrm{CH}_{2} \mathrm{Cl}_{2}$. The aqueous layer was extracted with $\mathrm{CH}_{2} \mathrm{Cl}_{2}$ three times, and the combined organic layers were washed with brine, washed over $\mathrm{Na}_{2} \mathrm{SO}_{4}$, filtered, and evaporated in vacuo. The products were then purified by preparative reversed-phase HPLC by UV detection and freeze-dried.

(E)-Methyl 3-(6-Methoxy-[1,1':3',1'-terphenyl]-3-yl)acrylate (13). The described procedure for Suzuki couplings method A was used with (E)-methyl 3-(3-chloro-4-methoxyphenyl)acrylate $(120 \mathrm{mg}$, $0.529 \mathrm{mmol}),\left[1,1^{\prime}\right.$-biphenyl]-3-ylboronic acid (130 mg, 0.656 $\mathrm{mmol}), \mathrm{KF}$ (155 mg, $2.67 \mathrm{mmol})$, SPhos $(67 \mathrm{mg}, 0.16 \mathrm{mmol})$, and $\mathrm{Pd}_{2}(\mathrm{dba})_{3}(48 \mathrm{mg}, 0.052 \mathrm{mmol})$ at $110{ }^{\circ} \mathrm{C}$ for $18 \mathrm{~h}$. The eluent used for purification was $17 \% \mathrm{v} / \mathrm{v}$ EtOAc in heptane to yield the title compound as a colorless oil, $180 \mathrm{mg}, 0.52 \mathrm{mmol}, 98 \%$ yield. Silica gel TLC $R_{f}=0.25$ (17\% v/v EtOAc in heptane); LC-MS (ESI): calcd for $\mathrm{C}_{23} \mathrm{H}_{20} \mathrm{O}_{3}[\mathrm{M}+\mathrm{H}]: 345.15$ observed 345.08, LC Rt $=8.52 \mathrm{~min} ;{ }^{1} \mathrm{H}$ $\operatorname{NMR}\left(400 \mathrm{MHz} \mathrm{CDCl}_{3}\right) \delta 7.74-7.66(\mathrm{~m}, 2 \mathrm{H}), 7.66-7.60(\mathrm{~m}, 2 \mathrm{H})$, $7.60-7.53(\mathrm{~m}, 2 \mathrm{H}), 7.52-7.47(\mathrm{~m}, 3 \mathrm{H}), 7.47-7.41(\mathrm{~m}, 2 \mathrm{H}), 7.40-$ $7.31(\mathrm{~m}, 1 \mathrm{H}), 6.98(\mathrm{~d}, J=8.5 \mathrm{~Hz}, 1 \mathrm{H}), 6.36(\mathrm{~d}, J=16.0 \mathrm{~Hz}, 1 \mathrm{H}), 3.83$ $(\mathrm{s}, 3 \mathrm{H}), 3.78(\mathrm{~s}, 3 \mathrm{H}) ;{ }^{13} \mathrm{C} \mathrm{NMR}\left(100 \mathrm{MHz}, \mathrm{CDCl}_{3}\right) \delta 167.84,158.44$, $144.54,141.26,141.25,138.25,131.25,130.64,129.34,128.86,128.62$, $128.50,128.45,127.42,127.37,127.33,126.30,115.76,111.47,55.87$, 51.71.

(E)-3-(6-Hydroxy-[1,1':3', 1'"terphenyl]-3-yl)acrylic Acid (2). The described procedure for deprotection, method $A$ was used with $(E)$ methyl 3-(6-methoxy-[1,1':3',1' -terphenyl]-3-yl) (13) (100 mg, 0.29 $\mathrm{mmol}$ ) to afford the title compound, 2, as a white amorphous powder after preparative reverse-phase HPLC and subsequent freeze-drying (34 mg, $0.107 \mathrm{mmol}, 37 \%$ over two steps). LC-MS (ESI): calcd for $\mathrm{C}_{21} \mathrm{H}_{16} \mathrm{O}_{3}[\mathrm{M}+\mathrm{H}]: 317.12$ observed 317.17, LC Rt $=6.52 \mathrm{~min} ;{ }^{1} \mathrm{H}$ $\operatorname{NMR}\left(400 \mathrm{MHz}, \mathrm{CDCl}_{3}\right) \delta 7.77(\mathrm{~d}, J=15.9 \mathrm{~Hz}, 1 \mathrm{H}), 7.71-7.55(\mathrm{~m}$, $5 \mathrm{H}), 7.54-7.42(\mathrm{~m}, 5 \mathrm{H}), 7.42-7.36(\mathrm{~m}, 1 \mathrm{H}), 7.04(\mathrm{~d}, J=8.7 \mathrm{~Hz}$, $1 \mathrm{H}), 6.36(\mathrm{~d}, \mathrm{~J}=15.9 \mathrm{~Hz}, 1 \mathrm{H}) ;{ }^{13} \mathrm{C}$ NMR $\left(100 \mathrm{MHz}, \mathrm{CDCl}_{3}\right) \delta$ $171.82,155.03,146.63,142.75,140.50,136.63,130.84,130.08,129.81$, $129.08,128.83,127.97,127.92,127.85,127.35,127.34,127.31,116.75$, 115.09; HRMS $(\mathrm{m} / \mathrm{z}):[\mathrm{M}+\mathrm{H}]^{+}$calcd 317.1178, found 317.1179 .

(E)-Methyl 3-(3'-Benzyl-6-methoxy-[1,1'-biphenyl]-3-yl)acrylate (14). The described procedure for Suzuki couplings method A was used with (E)-methyl 3-(3-chloro-4-methoxyphenyl)acrylate $(97 \mathrm{mg}$, $0.43 \mathrm{mmol}$ ), 2-(3-benzylphenyl)-4,4,5,5-tetramethyl-1,3,2-dioxaborolane (153 mg, $0.520 \mathrm{mmol}), \mathrm{KF}$ (125 mg, $2.15 \mathrm{mmol})$, SPhos (54 mg, $0.13 \mathrm{mmol})$, and $\mathrm{Pd}_{2}(\mathrm{dba})_{3}(39 \mathrm{mg}, 0.040 \mathrm{mmol})$ at $110{ }^{\circ} \mathrm{C}$ for $18 \mathrm{~h}$. The eluent used for purification was $17 \% \mathrm{v} / \mathrm{v}$ EtOAc in heptane to yield the title compound as a colorless oil, $146 \mathrm{mg}, 0.41 \mathrm{mmol}, 95 \%$ yield. Silica gel TLC $R_{f}=0.28$ (17\% v/v EtOAc in heptane); LC-MS (ESI): calcd for $\mathrm{C}_{24} \mathrm{H}_{22} \mathrm{O}_{3}[\mathrm{M}+\mathrm{H}]$ : 359.16 observed 359.08, $\mathrm{LC}, \mathrm{Rt}=$ $8.68 \mathrm{~min} ;{ }^{1} \mathrm{H}$ NMR $\left(400 \mathrm{MHz}, \mathrm{CDCl}_{3}\right) \delta 7.67(\mathrm{~d}, J=16.0 \mathrm{~Hz}, 1 \mathrm{H})$, $7.48-7.42(\mathrm{~m}, 2 \mathrm{H}), 7.37-7.25(\mathrm{~m}, 5 \mathrm{H}), 7.24-7.14(\mathrm{~m}, 4 \mathrm{H}), 6.92(\mathrm{~d}, J$ $=8.3 \mathrm{~Hz}, 1 \mathrm{H}), 6.33(\mathrm{~d}, J=16.0 \mathrm{~Hz}, 1 \mathrm{H}), 4.02(\mathrm{~s}, 2 \mathrm{H}), 3.77(\mathrm{~s}, 3 \mathrm{H})$, $3.77(\mathrm{~s}, 3 \mathrm{H}) ;{ }^{13} \mathrm{C}$ NMR $\left(100 \mathrm{MHz}, \mathrm{CDCl}_{3}\right) \delta 167.80,158.38,144.56$, $141.07,140.98,137.83,131.30,130.61,130.15,129.08,128.54,128.28$, 128.02, 127.31, 127.22, 126.17, 115.64, 111.41, 55.75, 51.67, 42.05 .

(E)-3-(3'-Benzyl-6-hydroxy-[1,1'-biphenyl]-3-yl)acrylic Acid (3). The described procedure for deprotection, method A was used with (E)-methyl 3-(3'-benzyl-6-methoxy-[1,1'-biphenyl]-3-yl)acrylate (14) $(60 \mathrm{mg}, 0.17 \mathrm{mmol}$ ) to afford the title compound, 3 , as a white amorphous powder after preparative reverse-phase HPLC and subsequent freeze-drying $(24 \mathrm{mg}, 0.073 \mathrm{mmol}, 43 \%$ over two steps). LC-MS (ESI): calcd for $\mathrm{C}_{22} \mathrm{H}_{18} \mathrm{O}_{3}[\mathrm{M}+\mathrm{H}]: 331.14$ observed 331.00, LC Rt $=6.65 \mathrm{~min} ;{ }^{1} \mathrm{H}$ NMR $\left(400 \mathrm{MHz}, \mathrm{CDCl}_{3}\right) \delta 7.75(\mathrm{~d}, J=15.9$ $\mathrm{Hz}, 1 \mathrm{H}), 7.49-7.40(\mathrm{~m}, 3 \mathrm{H}), 7.33-7.19(\mathrm{~m}, 8 \mathrm{H}), 6.99(\mathrm{~d}, J=8.4 \mathrm{~Hz}$, $1 \mathrm{H}), 6.33(\mathrm{~d}, J=15.9 \mathrm{~Hz}, 1 \mathrm{H}), 4.05(\mathrm{~s}, 2 \mathrm{H}) ;{ }^{13} \mathrm{C}$ NMR $(100 \mathrm{MHz}$, $\left.\mathrm{CDCl}_{3}\right) \delta 172.48,154.98,146.74,142.96,140.63,136.23,130.81$, $129.80,129.66,129.57,129.15,129.05,128.84,128.78,127.17,126.75$, 
126.50, 116.63, 115.08, 42.09; HRMS $(m / z):[\mathrm{M}+\mathrm{H}]^{+}$calcd 331.1334, found 331.1319.

(E)-Methyl 3-(3'-Isopropyl-6-methoxy-[1,1'-biphenyl]-3-yl)acrylate (15). The described procedure for Suzuki couplings method A was used with (E)-methyl 3-(3-chloro-4-methoxyphenyl)acrylate (145 mg, $0.640 \mathrm{mmol})$, (3-isopropylphenyl)boronic acid (128 mg, $0.780 \mathrm{mmol})$, KF (187 mg, $3.22 \mathrm{mmol})$, SPhos $(81 \mathrm{mg}, 0.20 \mathrm{mmol})$, and $\mathrm{Pd}_{2}(\mathrm{dba})_{3}(61 \mathrm{mg}, 0.066 \mathrm{mmol})$ at $110{ }^{\circ} \mathrm{C}$ for $18 \mathrm{~h}$. The eluent used for purification was $15 \% \mathrm{v} / \mathrm{v}$ EtOAc in heptane to yield the title compound as a colorless oil in a quantitative yield. Silica gel TLC $R_{f}=$ 0.35 (15\% v/v EtOAc in heptane); LC-MS (ESI): calcd for $\mathrm{C}_{20} \mathrm{H}_{22} \mathrm{O}_{3}$ $[\mathrm{M}+\mathrm{H}]: 311.16$ observed $311.08, \mathrm{LC}, \mathrm{Rt}=8.52 \mathrm{~min} ;{ }^{1} \mathrm{H}$ NMR (399 $\left.\mathrm{MHz}, \mathrm{CDCl}_{3}\right) \delta 7.70(\mathrm{~d}, J=16.0 \mathrm{~Hz}, 1 \mathrm{H}), 7.52-7.45(\mathrm{~m}, 2 \mathrm{H}), 7.41-$ $7.31(\mathrm{~m}, 4 \mathrm{H}), 6.96(\mathrm{~d}, J=8.5 \mathrm{~Hz}, 1 \mathrm{H}), 6.35(\mathrm{~d}, J=16.0 \mathrm{~Hz}, 1 \mathrm{H}), 3.83$ $(\mathrm{s}, 3 \mathrm{H}), 3.79(\mathrm{~s}, 3 \mathrm{H}), 2.96$ (hept, $J=6.9 \mathrm{~Hz}, 1 \mathrm{H}), 1.29(\mathrm{~d}, J=6.9 \mathrm{~Hz}$, $6 \mathrm{H}) ;{ }^{13} \mathrm{C} \mathrm{NMR}\left(100 \mathrm{MHz}, \mathrm{CDCl}_{3}\right) \delta 167.86,158.44,148.73,144.66$, $137.65,130.68,129.06,128.50,128.09,127.75,127.24,127.05,125.56$, 115.60, 111.42, 55.81, 51.69, 34.25, 24.14.

(E)-3-(6-Hydroxy-3'-isopropyl-[1,1'-biphenyl]-3-yl)acrylic Acid (4). The described procedure for deprotection, method A was used with (E)-methyl 3-(3'-isopropyl-6-methoxy-[1,1'-biphenyl]-3-yl)acrylate (15) $(100 \mathrm{mg}, 0.32 \mathrm{mmol})$ to afford the title compound, 4 , as a white amorphous powder after preparative reverse-phase HPLC and subsequent freeze-drying (45 $\mathrm{mg}, 0.16 \mathrm{mmol}, 50 \%$,over two steps). LC-MS (ESI): calcd for $\mathrm{C}_{18} \mathrm{H}_{18} \mathrm{O}_{3}[\mathrm{M}+\mathrm{H}]: 283.13$ observed 283.17, LC, Rt $=6.43 \mathrm{~min} ;{ }^{1} \mathrm{H}$ NMR $\left(400 \mathrm{MHz}, \mathrm{CDCl}_{3}\right) \delta 7.77(\mathrm{~d}, J=15.9$ $\mathrm{Hz}, 1 \mathrm{H}), 7.51-7.42(\mathrm{~m}, 3 \mathrm{H}), 7.34-7.27(\mathrm{~m}, 3 \mathrm{H}), 7.02(\mathrm{~d}, J=8.3 \mathrm{~Hz}$, $1 \mathrm{H}), 6.34(\mathrm{~d}, J=15.9 \mathrm{~Hz}, 1 \mathrm{H}), 2.98(\mathrm{~d}, J=6.9 \mathrm{~Hz}, 1 \mathrm{H}), 1.30(\mathrm{~d}, J=$ $6.9 \mathrm{~Hz}, 6 \mathrm{H}) ;{ }^{13} \mathrm{C} \mathrm{NMR}\left(100 \mathrm{MHz}, \mathrm{CDCl}_{3}\right) \delta 172.43,155.05,150.66$, $146.82,135.97,130.79,129.68,129.65,129.17,127.26,127.14,126.80$, 126.38, 116.57, 115.00, 34.34, 24.14; HRMS $(m / z):[\mathrm{M}+\mathrm{H}]^{+}$calcd 283.1334, found 283.1334 .

(E)-Methyl 3-(4-Methoxy-3-(4,4,5,5-tetramethyl-1,3,2-dioxaborolan-2-yl)phenyl)acrylate (12b). ${ }^{35}$ 1-Bromo-3-propylbenzene. To a solution of 3-bromopropiophenone (2.98 g, $14.0 \mathrm{mmol})$ in TFA (30 $\mathrm{mL}, 0.40 \mathrm{M})$ was added dropwise triethylsilane $(11.5 \mathrm{~mL}, 72.0 \mathrm{mmol})$ at $0{ }^{\circ} \mathrm{C}$ in $5 \mathrm{~min}$, and the mixture was stirred for additional $20 \mathrm{~min}$. The reaction mixture was heated to $80{ }^{\circ} \mathrm{C}$ and stirred overnight. The reaction mixture was allowed to cool to room temperature and concentrated in vacuo. Toluene was added, and the mixture was again concentrated in vacuo to obtain the crude material. The product was purified via flash silica gel chromatography eluting with hexane to yield the title compound, $78 \mathrm{mg}, 0.39 \mathrm{mmol}, 3 \%$ yield; ${ }^{1} \mathrm{H}$ NMR $(400 \mathrm{MHz}$, $\left.\mathrm{CDCl}_{3}\right): \delta(\mathrm{ppm}) 7.38-7.27(\mathrm{~m}, 2 \mathrm{H}), 7.18-7.06(\mathrm{~m}, 2 \mathrm{H}), 2.59-2.49$ (m, 2H), $1.72-1.56(\mathrm{~m}, 2 \mathrm{H}), 0.93(\mathrm{td}, J=7.3,0.9 \mathrm{~Hz}, 3 \mathrm{H}) ;{ }^{13} \mathrm{C}$ NMR $\left(100 \mathrm{MHz}, \mathrm{CDCl}_{3}\right): 145.16,131.65,129.91,128.87,127.28,122.45$, 37.81, 24.49, 13.87.

(E)-Methyl 3-(6-methoxy-3'-propyl-[1,1'-biphenyl]-3-yl)acrylate (16). The described procedure for Suzuki couplings method A was used with $(E)$-methyl 3-(4-methoxy-3-(4,4,5,5-tetramethyl-1,3,2-dioxaborolan-2-yl)phenyl)acrylate (152 mg, $0.478 \mathrm{mmol})$, 1-bromo-3propylbenzene $(78 \mathrm{mg}, 0.39 \mathrm{mmol}), \mathrm{KF}(114 \mathrm{mg}, 1.96 \mathrm{mmol})$, SPhos (49 mg, $0.12 \mathrm{mmol})$, and $\mathrm{Pd}_{2}(\mathrm{dba})_{3}(37 \mathrm{mg}, 0.040 \mathrm{mmol})$ at $100{ }^{\circ} \mathrm{C}$ for $7 \mathrm{~h}$. The eluent used for purification was $5 \%-10 \% \mathrm{v} / \mathrm{v}$ EtOAc in hexane to yield the title compound as a dark yellow oil, $95 \mathrm{mg}, 0.31$ mmol, 78\% yield; ${ }^{1} \mathrm{H}$ NMR $\left(400 \mathrm{MHz}, \mathrm{CDCl}_{3}\right): 7.69$ (d, $J=16.0 \mathrm{~Hz}$, $1 \mathrm{H}), 7.55-7.45(\mathrm{~m}, 2 \mathrm{H}), 7.36-7.30(\mathrm{~m}, 3 \mathrm{H}), 7.23-7.13(\mathrm{~m}, 1 \mathrm{H})$, $6.98(\mathrm{~d}, J=8.4 \mathrm{~Hz}, 1 \mathrm{H}), 6.35(\mathrm{~d}, J=16.0 \mathrm{~Hz}, 1 \mathrm{H}), 3.85(\mathrm{~s}, 3 \mathrm{H}), 3.80$ (s, 3H), 2.75-2.57 (m, $2 \mathrm{H}), 1.76-1.61(\mathrm{~m}, 2 \mathrm{H}), 0.98(\mathrm{t}, J=7.3 \mathrm{~Hz}$, $3 \mathrm{H}) ;{ }^{13} \mathrm{C}$ NMR $\left(100 \mathrm{MHz}, \mathrm{CDCl}_{3}\right): 167.90,158.50,144.68,142.66$, $137.65,130.69,129.73,129.12,128.54,128.08,127.68,127.30,126.94$, $115.68,111.45,55.89,51.75,38.27,24.73,14.07$.

(E)-3-(6-Hydroxy-3'-propyl-[1,1'-biphenyl]-3-yl)acrylic Acid (5). The described procedure for deprotection, method A was used with (E)-methyl 3-(6-methoxy-3'-propyl-[1,1'-biphenyl]-3-yl)acrylate (16), with the adjustment that the intermediate after treatment with $\mathrm{BBr}_{3}$ was purified using silica gel chromoatography eluting with $5 \%-10 \% \mathrm{v} /$ $\mathrm{v}$ EtOAc in hexane to yield the title compound, 5, as a yellow oil, 25 $\mathrm{mg}, 0.085 \mathrm{mmol}, 42 \%$ yield. On repeating the reaction a second time (25.1 $\mathrm{mg}, 0.084 \mathrm{mmol}$ ), the title compound was isolated in a $37 \%$ yield over two steps $(8.8 \mathrm{mg}, 0.03 \mathrm{mmol})$ as a white amorphous powder after preparative reverse-phase HPLC and subsequent freeze-drying. LC-MS (ESI): calcd for $\mathrm{C}_{18} \mathrm{H}_{18} \mathrm{O}_{3}[\mathrm{M}+\mathrm{H}]: 283.13$, observed 283.17, LC, Rt $=6.47 ;{ }^{1} \mathrm{H}$ NMR $\left(400 \mathrm{MHz}, \mathrm{CDCl}_{3}\right) \delta 7.76(\mathrm{~d}, J=15.9 \mathrm{~Hz}$, $1 \mathrm{H}), 7.53-7.36(\mathrm{~m}, 3 \mathrm{H}), 7.27-7.23(\mathrm{~m}, 3 \mathrm{H}), 7.01(\mathrm{~d}, J=8.2 \mathrm{~Hz}$, $1 \mathrm{H}), 6.33(\mathrm{~d}, J=15.9 \mathrm{~Hz}, 1 \mathrm{H}), 2.72-2.62(\mathrm{~m}, 2 \mathrm{H}), 1.75-1.66(\mathrm{~m}$, $2 \mathrm{H}), 0.98(\mathrm{t}, J=7.3 \mathrm{~Hz}, 3 \mathrm{H}) ;{ }^{13} \mathrm{C} \mathrm{NMR}\left(100 \mathrm{MHz}, \mathrm{CDCl}_{3}\right) \delta 172.22$, $155.07,146.83,144.45,135.93,130.77,129.64,129.58,129.19,129.08$, 128.78, 127.14, 126.26, 116.58, 114.95, 38.16, 24.69, 14.02 .

3-Chloro-2-methyl-1,1'-biphenyl (19). The described general Suzuki coupling conditions method B was used with 1-chloro-3iodo-2-methylbenzene $(275 \mu \mathrm{L}, 1.97 \mathrm{mmol})$, phenylboronic acid (364 $\mathrm{mg}, 2.99 \mathrm{mmol}), \mathrm{KOAc}(584 \mathrm{mg}, 5.95 \mathrm{mmol})$, and $\mathrm{Pd}(\mathrm{dppf}) \mathrm{Cl}_{2}(148$ $\mathrm{mg}, 0.181 \mathrm{mmol}$ ) at $90{ }^{\circ} \mathrm{C}$ for $5.5 \mathrm{~h}$. The eluent used for purification was heptane to yield the title compound as a colorless oil, $229 \mathrm{mg}, 1.13$ mmol, $57 \%$ yield. Silica gel TLC $R_{f}=0.56$ (heptane); GC-MS (EI) $\mathrm{m} /$ $z$ calc. for $\mathrm{C}_{13} \mathrm{H}_{11} \mathrm{Cl}$ : 202.05 , most abundant peaks observed: 202, 167; ${ }^{1} \mathrm{H}$ NMR $\left(400 \mathrm{MHz}, \mathrm{CDCl}_{3}\right) \delta 7.43-7.29(\mathrm{~m}, 4 \mathrm{H}), 7.28-7.21(\mathrm{~m}$, $2 \mathrm{H}), 7.18-7.03(\mathrm{~m}, 2 \mathrm{H}), 2.27(\mathrm{~s}, 3 \mathrm{H}) ;{ }^{13} \mathrm{C}$ NMR $\left(100 \mathrm{MHz}, \mathrm{CDCl}_{3}\right)$ $\delta 144.11,141.57,135.40,133.84,129.27,128.42,128.29,127.28$, $126.49,17.99$.

(E)-Methyl 3-(6-(Methoxymethoxy)-2'-methyl-[1, $1^{\prime}: 3^{\prime}, 1^{\prime \prime}$-terphenyl]-3-yl)acrylate (21). The described general Suzuki coupling conditions method A was used with (E)-methyl 3-(4-(methoxymethoxy)-3-(4,4,5,5-tetramethyl-1,3,2-dioxaborolan-2-yl)phenyl)acrylate (104 mg, $0.300 \mathrm{mmol}$ ), 3-chloro-2-methyl-1,1'-biphenyl ( $52 \mathrm{mg}, 0.26$ $\mathrm{mmol}), \mathrm{KF}(72 \mathrm{mg}, 1.2 \mathrm{mmol})$, SPhos $(32 \mathrm{mg}, 0.078 \mathrm{mmol})$, and $\mathrm{Pd}_{2}(\mathrm{dba})_{3}(25 \mathrm{mg}, 0.027 \mathrm{mmol})$ at $110{ }^{\circ} \mathrm{C}$ for $21 \mathrm{~h}$. The eluent used for purification was $17 \% \mathrm{v} / \mathrm{v}$ EtOAc in heptane to yield the title compound as a colorless oil in a quantitative yield. Silica gel TLC $R_{f}=$ 0.31 (heptane/EtOAc 17\% v/v); LC-MS (ESI): calcd for $\mathrm{C}_{25} \mathrm{H}_{24} \mathrm{O}_{4}$ $[\mathrm{M}+\mathrm{H}]: 389.18$ observed $389.08, \mathrm{LC}, \mathrm{Rt}=8.63 \mathrm{~min} .{ }^{1} \mathrm{H}$ NMR $(400$ $\left.\mathrm{MHz}, \mathrm{CDCl}_{3}\right): \delta 7.68(\mathrm{~d}, J=16.0 \mathrm{~Hz}, 1 \mathrm{H}), 7.49(\mathrm{dd}, J=8.6,2.3 \mathrm{~Hz}$, $1 \mathrm{H}), 7.45-7.32(\mathrm{~m}, 6 \mathrm{H}), 7.31-7.20(\mathrm{~m}, 3 \mathrm{H}), 7.18(\mathrm{dd}, J=7.0,2.1$ $\mathrm{Hz}, 1 \mathrm{H}), 6.35(\mathrm{~d}, J=16.0 \mathrm{~Hz}, 1 \mathrm{H}), 5.14(\mathrm{~s}, 2 \mathrm{H}), 3.79(\mathrm{~s}, 3 \mathrm{H}), 3.37(\mathrm{~s}$, $3 \mathrm{H}), 2.02(\mathrm{~s}, 3 \mathrm{H}) ;{ }^{13} \mathrm{C} \mathrm{NMR}\left(100 \mathrm{MHz}, \mathrm{CDCl}_{3}\right) \delta 167.77,156.38$, $144.46,142.45,142.43,138.75,134.27,132.90,131.03,129.50,129.16$, $129.10,128.26,128.19,126.92,125.33,116.25,115.08,94.72,56.33$, $51.74,18.18$.

(E)-3-(6-Hydroxy-2'-methyl-[1, 1':3', $1^{\prime \prime}$-terphenyl]-3-yl)acrylic Acid (6). The described procedure for deprotection, method B was used at $40{ }^{\circ} \mathrm{C}$ with (E)-methyl 3-(6-(methoxymethoxy)-2'-methyl-[1,1':3',1" terphenyl]-3-yl)acrylate (21). LC-MS (ESI): calcd for $\mathrm{C}_{22} \mathrm{H}_{18} \mathrm{O}_{3}[\mathrm{M}+$ $\mathrm{H}]: 331.13$ observed 331.17, LC, Rt $=6.67 \mathrm{~min} ;{ }^{1} \mathrm{H}$ NMR $(400 \mathrm{MHz}$, $\left.\mathrm{CDCl}_{3}\right) \delta 7.76(\mathrm{~d}, J=15.9 \mathrm{~Hz}, 1 \mathrm{H}), 7.51(\mathrm{dd}, J=8.5,2.2 \mathrm{~Hz}, 1 \mathrm{H})$, $7.47-7.32(\mathrm{~m}, 8 \mathrm{H}), 7.24(\mathrm{dd}, J=6.7,2.1 \mathrm{~Hz}, 1 \mathrm{H}), 7.04(\mathrm{~d}, J=8.4 \mathrm{~Hz}$, $1 \mathrm{H}), 6.34(\mathrm{~d}, J=15.9 \mathrm{~Hz}, 1 \mathrm{H}), 2.04(\mathrm{~s}, 3 \mathrm{H}) ;{ }^{13} \mathrm{C}$ NMR $(100 \mathrm{MHz}$, $\left.\mathrm{CDCl}_{3}\right) \delta 172.46,155.20,146.81,143.84,141.79,135.45,135.00$, $130.90,130.83,129.85,129.67,129.37,129.05,128.37,127.26,127.03$, 126.53, 116.25, 115.05, 17.94. HRMS $(\mathrm{m} / \mathrm{z}):[\mathrm{M}+\mathrm{H}]^{+}$calcd for $\mathrm{C}_{22} \mathrm{H}_{18} \mathrm{O}_{3}, 331.1334$, found 331.1331 .

3-Chloro-4-methyl-1,1'-biphenyl (20). The described general Suzuki coupling conditions method B was used with 2-chloro-4iodo-1-methylbenzene $(321 \mathrm{mg}, 1.27 \mathrm{mmol})$, phenylboronic acid (226 $\mathrm{mg}, 1.85 \mathrm{mmol}$ ), KOAc (354 mg, $3.61 \mathrm{mmol})$, and $\mathrm{Pd}(\mathrm{dppf}) \mathrm{Cl}_{2}$ (95 $\mathrm{mg}, 0.12 \mathrm{mmol})$ at $90{ }^{\circ} \mathrm{C}$ for $3.5 \mathrm{~h}$. The eluent used for purification was heptane to yield the title compound as a colorless oil, $124 \mathrm{mg}, 0.61$ mmol, $51 \%$ yield. Silica gel TLC $R_{f}=0.49$ (heptane); GC-MS (ESI) $m / z$ calc. for $\mathrm{C}_{13} \mathrm{H}_{11} \mathrm{Cl}$ : 202.05, most abundant peaks observed: 202 , 167; ${ }^{1} \mathrm{H}$ NMR (400 MHz, $\left.\mathrm{CDCl}_{3}\right) \delta 7.62-7.49(\mathrm{~m}, 3 \mathrm{H}), 7.47-7.29$ (m, 4H), 7.29-7.22 (m, 1H), $2.39(\mathrm{~s}, 3 \mathrm{H}) ;{ }^{13} \mathrm{C}$ NMR (100 MHz, $\left.\mathrm{CDCl}_{3}\right) \delta 140.56,139.88,134.98,134.87,131.35,128.96,127.70$, $127.67,127.04,125.37,19.85$.

(E)-Methyl 3-(6-(Methoxymethoxy)-6'-methyl-[1, $1^{\prime}: 3^{\prime}, 1^{\prime \prime}$-terphenyl]-3-yl)acrylate (22). The described general Suzuki coupling conditions method A was used with (E)-methyl 3-(4-(methoxymethoxy)-3-(4,4,5,5-tetramethyl-1,3,2-dioxaborolan-2-yl)phenyl)acrylate $(103 \mathrm{mg}, 0.300 \mathrm{mmol})$, 3-chloro-4-methyl-1,1'-biphenyl (48 mg, 0.24 $\mathrm{mmol}), \mathrm{KF}(72 \mathrm{mg}, 1.2 \mathrm{mmol})$, SPhos ( $32 \mathrm{mg}, 0.078 \mathrm{mmol})$, and $\mathrm{Pd}_{2}(\mathrm{dba})_{3}(23 \mathrm{mg}, 0.025 \mathrm{mmol})$ at $110{ }^{\circ} \mathrm{C}$ for $21 \mathrm{~h}$. The eluent used 
for purification was $17 \% \mathrm{v} / \mathrm{v}$ EtOAc in heptane to yield the title compound $65 \mathrm{mg}, 0.17 \mathrm{mmol}, 70 \%$ yield. Silica gel TLC $R_{f}=0.29$ (heptane/EtOAc 17\% v/v); LC-MS (ESI): calcd for $\mathrm{C}_{25} \mathrm{H}_{24} \mathrm{O}_{4}[\mathrm{M}+$ $\mathrm{H}]$ : 389.18 observed $389.08, \mathrm{LC}, \mathrm{Rt}=8.65 \mathrm{~min} ;{ }^{1} \mathrm{H} \mathrm{NMR}(400 \mathrm{MHz}$, $\left.\mathrm{CDCl}_{3}\right): \delta(\mathrm{ppm}) 7.69(\mathrm{~d}, J=16.0 \mathrm{~Hz}, 1 \mathrm{H}), 7.63-7.59(\mathrm{~m}, 2 \mathrm{H})$, $7.57-7.32(\mathrm{~m}, 9 \mathrm{H}), 6.36(\mathrm{~d}, J=16.0 \mathrm{~Hz}, 1 \mathrm{H}), 5.13(\mathrm{~s}, 2 \mathrm{H}), 3.79(\mathrm{~s}$, $3 \mathrm{H}), 3.36(\mathrm{~s}, 3 \mathrm{H}), 2.21(\mathrm{~s}, 3 \mathrm{H}) ;{ }^{13} \mathrm{C}$ NMR $\left(100 \mathrm{MHz}, \mathrm{CDCl}_{3}\right) \delta$ $167.76,156.42$, 144.42, 140.90, 138.60, 138.39, 135.96, 132.41, 130.98, $130.30,129.20,128.87,128.73,128.30,127.22,127.08,126.37,116.30$, $115.18,94.80,56.35,51.75,19.79$.

(E)-3-(6-Hydroxy-6'-methyl-[1, 1':3', $1^{\prime \prime}$-terphenyl]-3-yl)acrylic Acid (7). The described procedure for deprotection, method $\mathrm{B}$ was used at $40{ }^{\circ} \mathrm{C}$ with (E)-methyl 3-(6-(methoxymethoxy)-6'-methyl-[1,1 $: 3^{\prime}, 1^{\prime \prime}$ terphenyl]-3-yl)acrylate (22) (32 mg, $0.082 \mathrm{mmol}$ LC-MS (ESI): calcd for $\mathrm{C}_{22} \mathrm{H}_{18} \mathrm{O}_{3}[\mathrm{M}+\mathrm{H}]: 331.13$ observed 331.17, LC, $\mathrm{Rt}=6.67$ $\min ;{ }^{1} \mathrm{H}$ NMR $\left(400 \mathrm{MHz}, \mathrm{CDCl}_{3}\right) \delta 7.76(\mathrm{~d}, J=15.9 \mathrm{~Hz}, 1 \mathrm{H}), 7.64-$ $7.56(\mathrm{~m}, 3 \mathrm{H}), 7.52(\mathrm{dd}, J=8.5,2.2 \mathrm{~Hz}, 1 \mathrm{H}), 7.48(\mathrm{~d}, J=2.0 \mathrm{~Hz}, 1 \mathrm{H})$, $7.47-7.38(\mathrm{~m}, 4 \mathrm{H}), 7.38-7.31(\mathrm{~m}, 1 \mathrm{H}), 7.04(\mathrm{~d}, J=8.5 \mathrm{~Hz}, 1 \mathrm{H}), 6.33$ $(\mathrm{d}, J=15.9 \mathrm{~Hz}, 1 \mathrm{H}), 2.21(\mathrm{~s}, 3 \mathrm{H}) ;{ }^{13} \mathrm{C}$ NMR $\left(100 \mathrm{MHz}, \mathrm{CDCl}_{3}\right) \delta$ $172.26,155.19,146.75,140.26,139.90,136.44,135.16,131.56,130.85$, $129.92,129.15,129.02,128.52,127.73,127.63,127.10,127.06,116.30$, 115.05, 19.54. HRMS $(m / z):[\mathrm{M}+\mathrm{H}]^{+}$calcd for $\mathrm{C}_{22} \mathrm{H}_{18} \mathrm{O}_{3}, 331.1334$, found 331.1328 .

(E)-methyl 3-(5'-allyl-6-(methoxymethoxy)-2'-propoxy-[1,1'-biphenyl]-3-yl)acrylate (25). The described general Suzuki coupling conditions method A was used with (E)-methyl 3-(4-(methoxymethoxy)-3-(4,4,5,5-tetramethyl-1,3,2-dioxaborolan-2-yl)phenyl)acrylate (72 mg, $0.21 \mathrm{mmol}$ ), 4-allyl-2-chloro-1-propoxybenzene (40 mg, 0.19 $\mathrm{mmol}), \mathrm{KF}$ (52 mg, $0.90 \mathrm{mmol})$, SPhos $(22.2 \mathrm{mg}, 0.054 \mathrm{mmol})$, and $\mathrm{Pd}_{2}(\mathrm{dba})_{3}(17 \mathrm{mg}, 0.020 \mathrm{mmol})$ at $110^{\circ} \mathrm{C}$ for $21 \mathrm{~h}$. The eluent used for purification was $17 \% \mathrm{v} / \mathrm{v}$ EtOAc in heptane to yield the title compound, $67 \mathrm{mg}, 0.17 \mathrm{mmol}, 94 \%$ yield. Silica gel TLC $R_{f}=0.29$ (heptane/EtOAc 17\% v/v); LC-MS (ESI): calcd for $\mathrm{C}_{24} \mathrm{H}_{28} \mathrm{O}_{5}[\mathrm{M}+$ $\mathrm{H}]:$ 397.20, observed 397.00, LC, Rt $=8.80 ;{ }^{1} \mathrm{H}$ NMR $(400 \mathrm{MHz}$, Chloroform-d) $\delta 7.67(\mathrm{~d}, J=16.0 \mathrm{~Hz}, 1 \mathrm{H}), 7.49-7.38(\mathrm{~m}, 2 \mathrm{H}), 7.19$ $(\mathrm{d}, J=9.1 \mathrm{~Hz}, 1 \mathrm{H}), 7.13(\mathrm{dd}, J=8.3,2.3 \mathrm{~Hz}, 1 \mathrm{H}), 7.06(\mathrm{~d}, J=2.4 \mathrm{~Hz}$, $1 \mathrm{H}), 6.89(\mathrm{~d}, J=8.4 \mathrm{~Hz}, 1 \mathrm{H}), 6.33(\mathrm{~d}, J=16.0 \mathrm{~Hz}, 1 \mathrm{H}), 5.98(\mathrm{ddt}, J=$ $16.8,10.0,6.7 \mathrm{~Hz}, 1 \mathrm{H}), 5.17-4.95(\mathrm{~m}, 4 \mathrm{H}), 3.85(\mathrm{t}, J=6.5 \mathrm{~Hz}, 2 \mathrm{H})$, $3.78(\mathrm{~s}, 3 \mathrm{H}), 3.44-3.28(\mathrm{~m}, 5 \mathrm{H}), 1.68-1.56(\mathrm{~m}, 2 \mathrm{H}), 0.83(\mathrm{t}, J=7.4$ $\mathrm{Hz}, 3 \mathrm{H}) ;{ }^{13} \mathrm{C}$ NMR $\left(100 \mathrm{MHz}, \mathrm{CDCl}_{3}\right) \delta 167.73,156.79,154.86$, 144.64, 137.71, 131.64, 131.45, 131.44, 129.55, 128.77, 128.75, 127.73, $127.29,115.67,115.55,115.02,112.43,94.78,70.18,56.00,51.54$, 39.36, 22.56, 10.40 .

(E)-3-(5'-Allyl-6-hydroxy-2'-propoxy-[1,1'-biphenyl]-3-yl)acrylic Acid (9). The described procedure for deprotection, method $B$ was used at room temperature with methyl $(E)-3-\left(5^{\prime}\right.$-allyl-6-(methoxymethoxy)-2'-propoxy-[1,1'-biphenyl]-3-yl)acrylate (25) (31 mg, $0.078 \mathrm{mmol}$ ) LC-MS (ESI): calcd for $\mathrm{C}_{21} \mathrm{H}_{22} \mathrm{O}_{4}[\mathrm{M}+\mathrm{H}]: 339.16$ observed 339.0, LC, Rt $=6.82 \mathrm{~min} .{ }^{1} \mathrm{H}$ NMR $\left(400 \mathrm{MHz} \mathrm{CDCl}_{3}\right) \delta$ $7.79(\mathrm{~d}, J=15.9 \mathrm{~Hz}, 1 \mathrm{H}), 7.52(\mathrm{dd}, J=8.4,2.2 \mathrm{~Hz}, 1 \mathrm{H}), 7.47(\mathrm{~d}, J=$ $2.2 \mathrm{~Hz}, 1 \mathrm{H}), 7.22(\mathrm{dd}, J=8.4,2.2 \mathrm{~Hz}, 1 \mathrm{H}), 7.16(\mathrm{~d}, J=2.2 \mathrm{~Hz}, 1 \mathrm{H})$, $7.04(\mathrm{~d}, J=8.4 \mathrm{~Hz}, 1 \mathrm{H}), 7.00(\mathrm{~d}, J=8.4 \mathrm{~Hz}, 1 \mathrm{H}), 6.35(\mathrm{~d}, J=15.9 \mathrm{~Hz}$, $1 \mathrm{H}), 5.98(\mathrm{ddt}, J=16.8,10.1,6.7 \mathrm{~Hz}, 1 \mathrm{H}), 5.17-5.04(\mathrm{~m}, 2 \mathrm{H}), 4.02$ $(\mathrm{t}, J=6.7 \mathrm{~Hz}, 2 \mathrm{H}), 3.44-3.37(\mathrm{~m}, 2 \mathrm{H}), 1.76(\mathrm{dtd}, J=13.8,7.4,6.5 \mathrm{~Hz}$, $2 \mathrm{H}), 0.94(\mathrm{t}, J=7.4 \mathrm{~Hz}, 3 \mathrm{H}) ;{ }^{13} \mathrm{C} \mathrm{NMR}\left(100 \mathrm{MHz}, \mathrm{CDCl}_{3}\right) \delta 171.78$, $156.66,153.39,147.04,137.37,134.45,132.68,132.27,129.84,129.43$, $127.28,127.21,126.82,118.47,116.25,114.65,113.69,71.77,39.50$, 31.09, 22.61, 10.51; HRMS $(m / z):[\mathrm{M}+\mathrm{H}]^{+}$calcd for $\mathrm{C}_{21} \mathrm{H}_{22} \mathrm{O}_{4}$, 339.1596 , found 339.1592 .

(E)-Methyl 3-(5'-Allyl-2'-(hexyloxy)-6-(methoxymethoxy)-[1,1'-biphenyl]-3-yl)acrylate (26). The described general Suzuki coupling conditions method A was used with (E)-methyl 3-(4-(methoxymethoxy)-3-(4,4,5,5-tetramethyl-1,3,2-dioxaborolan-2-yl)phenyl)acrylate (66 mg, $0.19 \mathrm{mmol})$, 4-allyl-2-chloro-1-(hexyloxy)benzene $(40 \mathrm{mg}$, $0.16 \mathrm{mmol}), \mathrm{KF}(49 \mathrm{mg}, 0.84 \mathrm{mmol})$, SPhos $(20 \mathrm{mg}, 0.049 \mathrm{mmol})$, and $\mathrm{Pd}_{2}(\mathrm{dba})_{3}(16 \mathrm{mg}, 0.017 \mathrm{mmol})$ at $110{ }^{\circ} \mathrm{C}$ for $21 \mathrm{~h}$. The eluent used for purification was $17 \% \mathrm{v} / \mathrm{v}$ EtOAc in heptane to yield the title compound, $68 \mathrm{mg}, 0.15 \mathrm{mmol}, 98 \%$ yield. Silica gel TLC $R_{f}=0.39$ (heptane/EtOAc 17\% v/v); LC-MS (ESI): calcd for $\mathrm{C}_{27} \mathrm{H}_{34} \mathrm{O}_{5}[\mathrm{M}+$ $\mathrm{H}]:$ 439.25, observed 439.08, LC, Rt $=9.63 \mathrm{~min} ;{ }^{1} \mathrm{H}$ NMR $(399 \mathrm{MHz}$,
Chloroform-d) $\delta 7.67$ (d, $J=16.0 \mathrm{~Hz}, 1 \mathrm{H}), 7.48-7.39$ (m, 3H), 7.19 $(\mathrm{d}, J=9.1 \mathrm{~Hz}, 1 \mathrm{H}), 7.16-7.04(\mathrm{~m}, 1 \mathrm{H}), 6.90(\mathrm{~d}, J=8.3 \mathrm{~Hz}, 1 \mathrm{H}), 6.33$ $(\mathrm{d}, J=16.0 \mathrm{~Hz}, 1 \mathrm{H}), 5.98(\mathrm{ddt}, J=16.8,10.0,6.7 \mathrm{~Hz}, 1 \mathrm{H}), 5.17-4.97$ $(\mathrm{m}, 4 \mathrm{H}), 3.88(\mathrm{t}, J=6.5 \mathrm{~Hz}, 2 \mathrm{H}), 3.78(\mathrm{~s}, 3 \mathrm{H}), 3.37(\mathrm{~s}, 5 \mathrm{H}), 1.65-$ $1.48(\mathrm{~m}, 2 \mathrm{H}), 1.37-1.08(\mathrm{~m}, 6 \mathrm{H}), 0.85-0.76(\mathrm{~m}, 3 \mathrm{H}) ;{ }^{13} \mathrm{C}$ NMR $\left(100 \mathrm{MHz}, \mathrm{cdcl}_{3}\right) \delta 167.88,156.92,155.02,144.80,137.86,131.77$, $131.61,131.58,129.10,128.92,128.53,127.86,127.41,115.80,115.72$, $115.15,112.61,94.89,68.87,56.16,51.70,39.52,31.58,29.32,25.77$, 22.68, 14.11 .

(E)-3-(5'-Allyl-2'-(hexyloxy)-6-hydroxy-[1, 1'-biphenyl]-3-yl)acrylic Acid (10). The described procedure for deprotection, method B was used at room temperature with methyl (E)-3-(5'-allyl-2'-(hexyloxy)-6(methoxymethoxy)-[1,1'-biphenyl]-3-yl)acrylate (26) (17 mg, 0.039 mmol) LC-MS (ESI): calcd for $\mathrm{C}_{24} \mathrm{H}_{28} \mathrm{O}_{4}[\mathrm{M}+\mathrm{H}]: 381.21$ observed 381.00, LC, Rt $=7.83 \mathrm{~min} ;{ }^{1} \mathrm{H}$ NMR $\left(400 \mathrm{MHz}, \mathrm{CDCl}_{3}\right) \delta 7.79(\mathrm{~d}, J=$ $15.9 \mathrm{~Hz}, 1 \mathrm{H}), 7.51(\mathrm{dd}, J=8.4,2.2 \mathrm{~Hz}, 1 \mathrm{H}), 7.47(\mathrm{~d}, J=2.2 \mathrm{~Hz}, 1 \mathrm{H})$, $7.22(\mathrm{dd}, J=8.3,2.2 \mathrm{~Hz}, 1 \mathrm{H}), 7.16(\mathrm{~d}, J=2.2 \mathrm{~Hz}, 1 \mathrm{H}), 7.04(\mathrm{~d}, J=8.3$ $\mathrm{Hz}, 1 \mathrm{H}), 7.00(\mathrm{~d}, J=8.3 \mathrm{~Hz}, 1 \mathrm{H}), 6.35(\mathrm{~d}, J=15.9 \mathrm{~Hz}, 1 \mathrm{H}), 5.98(\mathrm{ddt}$, $J=16.8,10.1,6.7 \mathrm{~Hz}, 1 \mathrm{H}), 5.20-5.01(\mathrm{~m}, 2 \mathrm{H}), 4.04(\mathrm{t}, J=6.7 \mathrm{~Hz}$, $2 \mathrm{H}), 3.41(\mathrm{~d}, J=6.7 \mathrm{~Hz}, 2 \mathrm{H}), 1.72(\mathrm{p}, J=6.7 \mathrm{~Hz}, 2 \mathrm{H}), 1.44-1.12(\mathrm{~m}$, $6 \mathrm{H}), 0.83(\mathrm{t}, J=6.8 \mathrm{~Hz}, 3 \mathrm{H}) ;{ }^{13} \mathrm{C}$ NMR $\left(100 \mathrm{MHz}, \mathrm{CDCl}_{3}\right) \delta 172.27$, $156.68,153.45,147.06,137.38,134.46,132.64,132.26,129.84,129.44$, $127.30,127.22,126.88,118.49,116.24,114.76,113.78,70.35,39.51$, 31.48, 29.13, 25.57, 22.59, 14.05; HRMS $(\mathrm{m} / z):[\mathrm{M}+\mathrm{H}]^{+}$calcd for $\mathrm{C}_{24} \mathrm{H}_{28} \mathrm{O}_{4}, 381.2066$, found 381.2063 .

4-Bromo-2-chloro-1-(methoxymethoxy)benzene. To a solution of 4-bromo-2-chlorophenol (7.35 g, $35.4 \mathrm{mmol}, 1.0$ equiv) in $\mathrm{CH}_{2} \mathrm{Cl}_{2}$ (50 $\mathrm{mL}, 0.70 \mathrm{M})$ was added $N, N$-diisopropylethylamine $(18.5 \mathrm{~mL}, 106$ $\mathrm{mmol}, 3.0$ equiv) and $\mathrm{MOMCl}(5.38 \mathrm{~mL}, 70.8 \mathrm{mmol}, 2.0$ equiv). The reaction was stirred at room temperature for $17 \mathrm{~h}$. The reaction mixture was separated between $\mathrm{CH}_{2} \mathrm{Cl}_{2}$ and $\mathrm{H}_{2} \mathrm{O}$ and the aqueous layer was extracted twice with $\mathrm{CH}_{2} \mathrm{Cl}_{2}$. The combined organic layers were washed with brine, dried over $\mathrm{Na}_{2} \mathrm{SO}_{4}$, filtered, and concentrated in vacuo. The product was purified via flash silica gel chromatography eluting with $50 \% \mathrm{v} / \mathrm{v} \mathrm{CH}_{2} \mathrm{Cl}_{2}$ in heptane to yield the title compound as a colorless oil, $8.9 \mathrm{~g}, 35 \mathrm{mmol}, 99 \%$ yield. Silica gel TLC $R_{f}=0.51$ $\left(\mathrm{CH}_{2} \mathrm{Cl}_{2} /\right.$ heptane $\left.1 / 1 \mathrm{v} / \mathrm{v}\right) ;{ }^{1} \mathrm{H}$ NMR $\left(400 \mathrm{MHz}, \mathrm{CDCl}_{3}\right) \delta 7.51(\mathrm{~d}, J$ $=2.4 \mathrm{~Hz}, 1 \mathrm{H}), 7.30(\mathrm{dd}, J=8.8,2.4 \mathrm{~Hz}, 1 \mathrm{H}), 7.05(\mathrm{~d}, J=8.8 \mathrm{~Hz}, 1 \mathrm{H})$, $5.22(\mathrm{~s}, 2 \mathrm{H}), 3.50(\mathrm{~s}, 3 \mathrm{H}) ;{ }^{13} \mathrm{C}$ NMR $\left(100 \mathrm{MHz}, \mathrm{CDCl}_{3}\right) \delta 152.30$, 132.84, 130.72, 124.88, 117.74, 114.19, 95.36, 56.54.

(E)-Methyl 3-(3-Chloro-4-(methoxymethoxy)phenyl)acrylate (17). An oven-dried Schlenk tube was charged with 4-bromo-2-chloro-1(methoxymethoxy)benzene $(2.0 \mathrm{~g}, 8.0 \mathrm{mmol}, 1.0$ equiv), methyl acrylate $\left(3.0 \mathrm{~mL}, 33.1 \mathrm{mmol}, 4.1\right.$ equiv), $\mathrm{Pd}(\mathrm{dppf}) \mathrm{Cl}_{2}(0.94 \mathrm{~g}, 1.2$ mmol, 0.15 equiv), $\mathrm{NEt}_{3}(35 \mathrm{~mL}, 251 \mathrm{mmol}, 31$ equiv), and DMF (20 $\mathrm{mL}, 0.40 \mathrm{M}$ ), and the reaction was stirred at $110^{\circ} \mathrm{C}$. After $20 \mathrm{~h}$, the reaction mixture was poured into $\mathrm{H}_{2} \mathrm{O}$ and extracted with $\mathrm{CH}_{2} \mathrm{Cl}_{2}$ three times. The combined organic layers were washed with brine, dried over $\mathrm{Na}_{2} \mathrm{SO}_{4}$, filtered, and concentrated in vacuo. The product was purified via flash silica gel chromatography, eluting with $20 \% \mathrm{v} / \mathrm{v}$ EtOAc in heptane to yield the title compound as a white solid, $1.6 \mathrm{~g}$, $6.2 \mathrm{mmol}, 78 \%$ yield. Silica gel TLC $R_{f}=0.34$ (heptane/EtOAc $20 \%$ $\mathrm{v} / \mathrm{v}$ ); GC-MS (ESI) $\mathrm{m} / z$ calcd for $\mathrm{C}_{12} \mathrm{H}_{13} \mathrm{ClO}_{4}$ : 256.05, most abundant peaks observed: 256, 226, 195; ${ }^{1} \mathrm{H}$ NMR (400 $\mathrm{MHz}$, $\left.\mathrm{CDCl}_{3}\right) \delta 7.61-7.55(\mathrm{~m}, 2 \mathrm{H}), 7.36(\mathrm{dd}, J=8.6,2.0 \mathrm{~Hz}, 1 \mathrm{H}), 7.18(\mathrm{~d}, J$ $=8.6 \mathrm{~Hz}, 1 \mathrm{H}), 6.33(\mathrm{~d}, J=15.9 \mathrm{~Hz}, 1 \mathrm{H}), 5.28(\mathrm{~s}, 2 \mathrm{H}), 3.80(\mathrm{~s}, 3 \mathrm{H})$, $3.52(\mathrm{~s}, 3 \mathrm{H}) ;{ }^{13} \mathrm{C} \mathrm{NMR}\left(100 \mathrm{MHz}, \mathrm{CDCl}_{3}\right) \delta 167.41,154.45,143.15$, $129.75,129.27,128.04,124.24,117.37,116.14,95.08,56.63,51.87$.

(E)-Methyl 3-(4-(Methoxymethoxy)-3-(4,4,5,5-tetramethyl-1,3,2dioxaborolan-2-yl)phenyl)acrylate (18). An oven-dried Schlenk tube was charged with (E)-methyl 3-(3-chloro-4-(methoxymethoxy)phenyl)acrylate (489 mg, $1.91 \mathrm{mmol}, 1.0$ equiv), KOAc (573 mg, 5.84 mmol, 3.1 equiv), bis(pinacolato)diboron ( $1.34 \mathrm{~g}, 5.28 \mathrm{mmol}, 2.8$ equiv), Xphos (78 mg, $0.16 \mathrm{mmol}, 0.080$ equiv), and $\mathrm{Pd}(\mathrm{OAc})_{2}(22$ $\mathrm{mg}, 0.098 \mathrm{mmol}, 0.051$ equiv). The Schlenk tube was evacuated and backfilled with argon three times. Dioxane $(6.5 \mathrm{~mL}$, aryl halide concentration $0.30 \mathrm{M}$ ) was added under a positive argon flow, and the reaction was stirred at $110^{\circ} \mathrm{C}$ for $5 \mathrm{~h}$. The reaction mixture was then allowed to cool to room temperature and passed through Celite, eluting with EtOAc. The product was purified via flash silica gel 
chromatography eluting with $25 \% \mathrm{v} / \mathrm{v}$ EtOAc in heptane to yield the title compound, $524 \mathrm{mg}, 1.51 \mathrm{mmol}, 80 \%$ yield. Silica gel TLC $R_{f}=$ 0.25 (heptane/EtOAc 25\% v/v); LC-MS (ESI): calcd for $\mathrm{C}_{18} \mathrm{H}_{25} \mathrm{BO}_{6}$ $[\mathrm{M}+\mathrm{H}]: 349.18$, observed 348.92, LC, $\mathrm{Rt}=7.42 ;{ }^{1} \mathrm{H}$ NMR $(400$ $\left.\mathrm{MHz}, \mathrm{CDCl}_{3}\right) \delta 7.87(\mathrm{~d}, J=2.3 \mathrm{~Hz}, 1 \mathrm{H}), 7.65(\mathrm{~d}, J=16.0 \mathrm{~Hz}, 1 \mathrm{H})$, $7.53(\mathrm{dd}, J=8.6,2.3 \mathrm{~Hz}, 1 \mathrm{H}), 7.03(\mathrm{~d}, J=8.6 \mathrm{~Hz}, 1 \mathrm{H}), 6.36(\mathrm{~d}, J=$ $16.0 \mathrm{~Hz}, 1 \mathrm{H}), 5.22(\mathrm{~s}, 2 \mathrm{H}), 3.78(\mathrm{~s}, 3 \mathrm{H}), 3.49(\mathrm{~s}, 3 \mathrm{H}), 1.35(\mathrm{~s}, 12 \mathrm{H})$; ${ }^{13} \mathrm{C}$ NMR $\left(100 \mathrm{MHz}, \mathrm{CDCl}_{3}\right) \delta 167.82,163.36,144.49,136.92$, 132.38, 128.00, 116.05, 115.18, 94.78, 83.89, 56.35, 51.71, 24.97.

4-Bromo-2-chloro-1-propoxybenzene. 4-Bromo-2-chlorophenol $(4.0 \mathrm{~g}, 19 \mathrm{mmol}, 1.0$ equiv) was dissolved in dry DMF $(100 \mathrm{~mL}$, concentration $0.20 \mathrm{M}$ ) in an oven-dried round-bottom flask. To this solution, $\mathrm{K}_{2} \mathrm{CO}_{3}(8.0 \mathrm{~g}, 58 \mathrm{mmol}, 3.1$ equiv) and 1-bromopropane ( 8.8 $\mathrm{mL}, 96 \mathrm{mmol}$, 5.1 equiv) were added, and the reaction was stirred at $70{ }^{\circ} \mathrm{C}$ for $22 \mathrm{~h}$. The reaction was then quenched with $\mathrm{H}_{2} \mathrm{O}$ and extracted with $\mathrm{CH}_{2} \mathrm{Cl}_{2}$ three times. The combined organic layers were washed with brine, dried over $\mathrm{Na}_{2} \mathrm{SO}_{4}$, filtered, and concentrated in vacuo. The product was purified via flash silica gel chromatography, eluting with $5 \% \mathrm{v} / \mathrm{v}$ EtOAc in heptane to yield fourthe title compound as a colorless oil, $4.7 \mathrm{~g}, 19 \mathrm{mmol}$, 98\% yield. Silica gel TLC $R_{f}=0.46$ (heptane/EtOAc $5 \%$ v/v); GC-MS (ESI) $\mathrm{m} / z$ calcd for $\mathrm{C}_{9} \mathrm{H}_{10} \mathrm{BrClO}$ : 249.53, most abundant peaks observed: $250,210,208, \mathrm{Rt}=5.04 ;{ }^{1} \mathrm{H}$ NMR (400 MHz, $\left.\mathrm{CDCl}_{3}\right): \delta(\mathrm{ppm}) 7.45(\mathrm{~d}, J=2.4 \mathrm{~Hz}, 1 \mathrm{H}), 7.25(\mathrm{dd}$, $J=8.7,2.4 \mathrm{~Hz}, 1 \mathrm{H}), 6.72(\mathrm{~d}, J=8.7 \mathrm{~Hz}, 1 \mathrm{H}), 3.94(\mathrm{t}, J=6.6 \mathrm{~Hz}, 2 \mathrm{H})$, 1.53-1.40 (m, 2H), 0.95-0.82 (m, 3H).); ${ }^{13} \mathrm{C}$ NMR (50 MHz, $\left.\mathrm{CDCl}_{3}\right) \delta 153.99,132.62,130.48,124.07,114.49,112.26,70.84,22.52$, 10.54 .

4-Allyl-2-chloro-1-propoxybenzene (23). An oven dried Schlenk flask was charged with 4-bromo-2-chloro-1-propoxybenzene (1.02 g, $4.09 \mathrm{mmol}, 1.0$ equiv), $\mathrm{CsF}(1.31 \mathrm{~g}, 8.62 \mathrm{mmol}, 2.1$ equiv), and $\mathrm{Pd}\left(\mathrm{PPh}_{3}\right)_{4}$ (467 mg, $0.404 \mathrm{mmol}, 0.099$ equiv). The flask was then evacuated and backfilled with argon three times, and THF $(34 \mathrm{~mL}$, aryl halide concentration $0.12 \mathrm{M}$ ) was added. The mixture was stirred for $30 \mathrm{~min}$ at room temperature before 2-allyl-4,4,5,5-tetramethyl-1,3,2dioxaborolane ( $1.35 \mathrm{~mL}, 7.21 \mathrm{mmol}, 1.8$ equiv) was added, and the reaction was stirred at $78^{\circ} \mathrm{C}$ for $22 \mathrm{~h}$. Another portion of CsF $(1.26 \mathrm{~g}$, $8.29 \mathrm{mmol}, 2.0$ equiv), $\mathrm{Pd}\left(\mathrm{PPh}_{3}\right)_{4}$ (467 mg, $0.404 \mathrm{mmol}, 0.099$ equiv), and THF $(30 \mathrm{~mL})$ was added, and the reaction was stirred at $78{ }^{\circ} \mathrm{C}$ for another $24 \mathrm{~h}$. The reaction was then allowed to cool to room temperature and was separated between pentane and $\mathrm{H}_{2} \mathrm{O}$. The aqueous layer was washed with pentane twice, and the combined organic layers were washed with brine, dried over $\mathrm{Na}_{2} \mathrm{SO}_{4}$, filtered twice, and concentrated in vacuo. The product was purified via flash silica gel chromatography eluting with $5 \% \mathrm{v} / \mathrm{v}$ EtOAc in heptane to yield the title compound as colorless oil, $690 \mathrm{mg}, 3.27 \mathrm{mmol}, 82 \%$ yield. Silica gel TLC $R_{f}=0.58$ (heptane/EtOAc 5\% v/v); GC-MS (ESI) $\mathrm{m} / z$ calcd for $\mathrm{C}_{12} \mathrm{H}_{15} \mathrm{ClO}$ : 210.70, most abundant peaks observed: $210,168,133, \mathrm{Rt}=5.02 ;{ }^{1} \mathrm{H}$ NMR $\left(400 \mathrm{MHz}, \mathrm{CDCl}_{3}\right) \delta$ $7.18(\mathrm{~d}, J=2.2 \mathrm{~Hz}, 1 \mathrm{H}), 6.98(\mathrm{dd}, J=8.4,2.2 \mathrm{~Hz}, 1 \mathrm{H}), 6.82(\mathrm{~d}, J=8.4$ $\mathrm{Hz}, 1 \mathrm{H}), 6.04-5.70(\mathrm{~m}, 1 \mathrm{H}), 5.10-5.06(\mathrm{~m}, 1 \mathrm{H}), 5.06-5.01(\mathrm{~m}, 1 \mathrm{H})$, $3.95(\mathrm{t}, J=6.5 \mathrm{~Hz}, 2 \mathrm{H}), 3.54-2.99(\mathrm{~m}, 2 \mathrm{H}), 1.91-1.76(\mathrm{~m}, 2 \mathrm{H}), 1.05$ $(\mathrm{t}, J=7.4 \mathrm{~Hz}, 3 \mathrm{H}) ;{ }^{13} \mathrm{C} \mathrm{NMR}\left(50 \mathrm{MHz}, \mathrm{CDCl}_{3}\right) \delta 153.04,137.21$, $133.11,130.36,127.70,122.87,116.11,113.56,70.82,39.14,22.66$, 10.61 .

4-Bromo-2-chloro-1-(hexyloxy)benzene. 4-Bromo-2-chlorophenol (4.0 g, $19 \mathrm{mmol})$ was dissolved in dry DMF (100 mL, final concentration $0.19 \mathrm{M}$ ) in an oven-dried round-bottom flask. To this solution was added $\mathrm{K}_{2} \mathrm{CO}_{3}(8.0 \mathrm{~g}, 58 \mathrm{mmol}, 3.1$ equiv) and 1bromohexane $\left(14 \mathrm{~mL}, 1.0 \times 10^{2} \mathrm{mmol}, 5.3\right.$ equiv), and the reaction was stirred at $70{ }^{\circ} \mathrm{C}$ for $18 \mathrm{~h}$. The reaction was separated between $\mathrm{H}_{2} \mathrm{O}$ and $\mathrm{CH}_{2} \mathrm{Cl}_{2}$ and the aqueous layer was washed with $\mathrm{CH}_{2} \mathrm{Cl}_{2}$ twice. The combined organic layers were washed with brine, dried over $\mathrm{Na}_{2} \mathrm{SO}_{4}$, filtered, and concentrated in vacuo. The product was purified via flash silica gel chromatography eluting with $5 \% \mathrm{v} / \mathrm{v}$ EtOAc in hexane to yield the title compound as a colorless oil, $5.5 \mathrm{~g}, 19 \mathrm{mmol}$, $98 \%$ yield. Silica gel TLC $R_{f}=0.70$ (hexane/EtOAc $5 \% \mathrm{v} / \mathrm{v}$ ). GC-MS (ESI) $\mathrm{m} / z$ calcd for $\mathrm{C}_{12} \mathrm{H}_{16} \mathrm{BrClO}$ : 291.6, most abundant peaks observed: 292, 210, 208, Rt $=6.25$; ${ }^{1} \mathrm{H}$ NMR $\left(400 \mathrm{MHz}, \mathrm{CDCl}_{3}\right): \delta$ $(\mathrm{ppm}) 7.45(\mathrm{~d}, J=2.5 \mathrm{~Hz}, 1 \mathrm{H}), 7.25(\mathrm{dd}, J=8.7,2.4 \mathrm{~Hz}, 1 \mathrm{H}), 6.72(\mathrm{~d}$, $J=8.8 \mathrm{~Hz}, 1 \mathrm{H}), 3.94(\mathrm{t}, J=6.6 \mathrm{~Hz}, 2 \mathrm{H}), 1.87-1.71(\mathrm{~m}, 2 \mathrm{H}), 1.53-$ $1.40(\mathrm{~m}, 2 \mathrm{H}), 1.40-1.24(\mathrm{~m}, 4 \mathrm{H}), 0.95-0.82(\mathrm{~m}, 3 \mathrm{H}) ;{ }^{13} \mathrm{C} \mathrm{NMR}$ $\left(100 \mathrm{MHz}, \mathrm{CDCl}_{3}\right) \delta 154.04,132.68,130.53,124.10,114.47,112.26$, 69.44, 31.60, 29.08, 25.69, 22.68, 14.11 .

4-Allyl-2-chloro-1-(hexyloxy)benzene (24). An oven-dried Schlenk flask was charged with 4-bromo-2-chloro-1-(hexyloxy)benzene (1.01 g, $3.47 \mathrm{mmol}, 1.0$ equiv), CsF (1.12 g, $7.37 \mathrm{mmol}, 2.1$ equiv), and $\mathrm{Pd}\left(\mathrm{PPh}_{3}\right)_{4}$ (397 mg, $0.344 \mathrm{mmol}, 0.099$ equiv). The flask was evacuated and backfilled with argon three times, and THF $(22 \mathrm{~mL}$, aryl halide concentration $0.16 \mathrm{M}$ ) was added. The mixture was stirred for $30 \mathrm{~min}$ at room temperature, and then 2-allyl-4,4,5,5-tetramethyl-1,3,2dioxaborolane ( $1.16 \mathrm{~mL}, 6.17 \mathrm{mmol}, 1.8$ equiv) and THF $(7.5 \mathrm{~mL})$ were added. The reaction was stirred at $78{ }^{\circ} \mathrm{C}$ for $21 \mathrm{~h}$. Another portion of CsF (1.12 g, $7.37 \mathrm{mmol}, 2.1$ equiv), $\mathrm{Pd}\left(\mathrm{PPh}_{3}\right)_{4}(401 \mathrm{mg}$, $0.347 \mathrm{mmol}, 0.010$ equiv), and THF $(30 \mathrm{~mL})$ was added, and the mixture was stirred at $78{ }^{\circ} \mathrm{C}$ for another $24 \mathrm{~h}$. The mixture was allowed to cool to room temperature and was separated between pentane and $\mathrm{H}_{2} \mathrm{O}$. The aqueous layer was washed with pentane twice and the combined organic layers were washed with brine, dried over $\mathrm{Na}_{2} \mathrm{SO}_{4}$, filtered, and concentrated in vacuo. The product was purified via flash silica gel chromatography eluting with $3 \% \mathrm{v} / \mathrm{v}$ EtOAc in heptane to yield the title compound as a colorless oil, $789 \mathrm{mg}, 3.12$ mmol, 91\% yield. Silica gel TLC $R_{f}=0.38$ (heptane/EtOAc 3\% v/v); GC-MS (ESI) $m / z$ calcd for $\mathrm{C}_{15} \mathrm{H}_{21} \mathrm{ClO}: 252.78$, most abundant peaks observed: 252, 168, 133, Rt $=6.21 ;{ }^{1} \mathrm{H}$ NMR $\left(400 \mathrm{MHz}, \mathrm{CDCl}_{3}\right) \delta$ $7.18(\mathrm{~d}, J=2.2 \mathrm{~Hz}, 1 \mathrm{H}), 7.00(\mathrm{dd}, J=8.4,2.2 \mathrm{~Hz}, 1 \mathrm{H}), 6.84(\mathrm{~d}, J=8.4$ $\mathrm{Hz}, 1 \mathrm{H}), 5.92(\mathrm{ddt}, J=17.6,9.5,6.7 \mathrm{~Hz}, 1 \mathrm{H}), 5.12-5.05(\mathrm{~m}, 1 \mathrm{H})$, $5.08-5.01(\mathrm{~m}, 1 \mathrm{H}), 4.00(\mathrm{t}, J=6.7 \mathrm{~Hz}, 2 \mathrm{H}), 3.30(\mathrm{dt}, \mathrm{J}=6.7,1.5 \mathrm{~Hz}$, $2 \mathrm{H}), 1.88-1.72(\mathrm{~m}, 2 \mathrm{H}), 1.57-1.42(\mathrm{~m}, 2 \mathrm{H}), 1.41-1.28(\mathrm{~m}, 4 \mathrm{H})$, $0.90(\mathrm{td}, \mathrm{J}=5.9,4.7,3.5 \mathrm{~Hz}, 3 \mathrm{H})) ;{ }^{13} \mathrm{C} \mathrm{NMR}\left(100 \mathrm{MHz}, \mathrm{CDCl}_{3}\right) \delta$ $153.11,137.26,133.16,130.41,127.71,122.94,116.15,113.64,69.47$, 39.18, 31.69, 29.27, 25.79, 22.74, 14.17.

Mammalian Two-Hybrid (M2H) Assays. Mammalian two-hybrid $(\mathrm{M} 2 \mathrm{H})$ assays were performed as previously described. ${ }^{35}$

General Considerations for Protein Expression and Purification. All solutions and equipment used in the handling of microbial cultures were autoclaved or sterile filtered. Media, plastic, and glassware were autoclaved at $121{ }^{\circ} \mathrm{C}$ for $20 \mathrm{~min}$ prior to use. Bacterial cultures were incubated in a New Brunswick Series 25 shaker. Centrifugation was performed in a Beckman Coulter Avanti J-25 centrifuge. Microcentrifugation was performed in an Eppendorf centrifuge 5415R or a Beckman Coulter microfuge 18. All biological laboratory buffers and media were bought from common suppliers and used as purchased. BL21(DE3) and NovaBlue Escherichia coli competent cells were purchased from Novagen, XL-10. DNA and protein concentration was determined using a NanoDrop 1000 spectrometer from Thermo Scientific using 260 and $280 \mathrm{~nm}$ wavelength, respectively. Gel electrophoresis for proteins was performed using 12\% SDS-PAGE gels in running buffer and visualized using InstantBlue stain. Protein concentration was determined using a NanoDrop 1000 spectrometer with a wavelength ratio of $280-260 \mathrm{~nm}$. The fluorescent D22 coactivator peptide was purchased from Invitrogen life technologies. $\operatorname{RXR} \alpha$-NURR1 heterodimerization and $\operatorname{RXR} \alpha$ homodimerization BRET2 assays were performed as described. ${ }^{2,33}$ Briefly, RXR $\alpha$ and NURR1 receptors were tagged with GFP and renilla luciferase. $\mathrm{pEC}_{50}$ is the negative logarithm of the $\mathrm{EC}_{50}$ in molar, and efficacies were compared to that of LG100268 (100\%). Values represent mean (SD) of three or more independent experiments.

Fluorescence Polarization Assay. $\mathrm{His}_{6}-\mathrm{RXR} \alpha$-LBD $(1 \mu \mathrm{M})$, fluorescein-labeled D22 coactivator peptide $(0.1 \mu \mathrm{M})$, and the ligand at the indicated concentration in buffer containing $100 \mathrm{mM}$ HEPES ( $\mathrm{pH} 7.5), 100 \mathrm{mM} \mathrm{NaCl}, 5 \mathrm{mM} \mathrm{DTT}$, and $0.1 \%$ bovine serum albumin were incubated for $60 \mathrm{~min}$ at $4{ }^{\circ} \mathrm{C}$ and protected from light. Conditions for the competition assay: $\mathrm{His}_{6}-\mathrm{RXR} \alpha$-LBD $(500 \mathrm{nM})$, fluorescein-labeled D22 coactivator peptide (50 nM), LG100268 (50 $\mathrm{nM})$. Fluorescent polarization signals $(\mathrm{mP})$ were measured with a Tecan Infinite F500 plate reader. Experiments were performed in triplicate, and the data were analyzed using Origin software.

Expression, Purification, and Crystallization of the RXR $L B D$. The histidine-tagged LBD of human RXR $\alpha$ (in a pET15b vector) was expressed in E. coli BL21(DE3). Cells were grown at $37{ }^{\circ} \mathrm{C}$ in $\mathrm{LB}$ 
medium supplemented with $100 \mathrm{mg} \mathrm{mL}^{-1}$ ampicillin until $\mathrm{OD}_{600}$ reached about 0.7 . Expression of $\mathrm{T} 7$ polymerase was induced by addition of isopropyl- $b$-d-thiogalactoside (IPTG) to a final concentration of $0.1 \mathrm{mM}$. After an additional incubation for $15 \mathrm{~h}$ at $15{ }^{\circ} \mathrm{C}$, and cell cultures were harvested by centrifugation at $8000 \mathrm{~g}$ for $20 \mathrm{~min}$. The cell pellet from $2 \mathrm{~L}$ of RXR $\alpha$ LBD was resuspended in $50 \mathrm{~mL}$ buffer A (20 mM Tris- $\mathrm{HCl} \mathrm{pH} 8.0,500 \mathrm{mM} \mathrm{NaCl}, 5 \mathrm{mM}$ imidazole) supplemented with a protease inhibitor (PMSF) and DNase I. The suspension was then lysed by sonication and centrifuged at $35000 \mathrm{~g}$ and $4{ }^{\circ} \mathrm{C}$ for $45 \mathrm{~min}$. The supernatant was loaded onto a $5 \mathrm{~mL} \mathrm{Ni}^{2+}$ affinity column, preequilibrated with buffer $\mathrm{A}$. The column was washed with 10 volumes of buffer $A$ and 10 volumes of buffer $A$ supplemented with $50 \mathrm{mM}$ imidazole. Bound proteins were eluted with buffer A containing $200 \mathrm{mM}$ imidazole. The fractions containing RXR LBD were pooled, concentrated, and desalted to buffer B (10 mM Tris- $\mathrm{HCl}$ $\mathrm{pH} 7.5,150 \mathrm{mM} \mathrm{NaCl}, 5 \mathrm{mM}$ DTT). To remove the histidine-tag, the protein was incubated for $16 \mathrm{~h}$ at $4{ }^{\circ} \mathrm{C}$ with thrombin $(1 \mathrm{unit} / \mathrm{mg}$ RXR). The protein was passed through a $\mathrm{Ni}^{2+}$ column and a superdex gel filtration column. The protein was concentrated and stored at -80 ${ }^{\circ} \mathrm{C}$ until further use.

Before crystallization, the protein was mixed with a 1.5 -fold molar excess of ligand and a 3 -fold excess of TIF2 NR2 cofactor peptide (686-KHKILHRLLQDSS-698). The complex was incubated for $1 \mathrm{~h}$ at $4{ }^{\circ} \mathrm{C}$. Drops with a size of $2-3 \mu \mathrm{L}$ using different reservoir to protein ratio were manually mixed and equilibrated against reservoirs with a volume of $500 \mathrm{~mL}$. Optimal crystals were grown in a week in $3 \mu \mathrm{L}$ drops with protein solution to reservoir ratio of 2:1 with 0.1 M PIPES, $\mathrm{pH} 7.0,0.1 \mathrm{M} \mathrm{NaCl}, 22 \%$ PEG $2 \mathrm{~K}$ MME. The crystals were cryocooled in liquid nitrogen using sucrose as cryo-protectant for X-ray data collection. Diffraction data for RXR were collected at the DESY beamline (Deutsches Elektronen-Synchrotron, Hamburg, Germany). The data set was indexed and integrated using iMosflm and scaled using SCALA. The structure was phased by molecular replacement using PDB ID 5EC9 as search model in Phaser. Coot and phenix.refine were used in alternating cycles of model building and refinement. All data collection, refinement, and validation statistics are shown in Table S1.

\section{ASSOCIATED CONTENT}

\section{S Supporting Information}

The Supporting Information is available free of charge on the ACS Publications website at DOI: 10.1021/acschemneuro.7b00216.

Supporting table and figures; ${ }^{1} \mathrm{H}$ NMR, ${ }^{13} \mathrm{C}$ NMR, and LC-MS analytical data of all new compounds; protein crystallography data (PDF)

\section{AUTHOR INFORMATION}

\section{Corresponding Authors}

*E-mail: 1.milroy@tue.nl.

*E-mail: 1.brunsveld@tue.nl.

\section{ORCID $\odot$}

Christian Ottmann: 0000-0001-7315-0315

Luc Brunsveld: 0000-0001-5675-511X

\section{Author Contributions}

The manuscript was written through contributions of all authors. M.S. and F.A.M. performed synthesis; M.S., F.A.M., and J.-N.M. performed biochemical and cellular studies; M.S., S.A.A., R.M.J.M.d.V., and C.O. performed structural characterization and analysis; E.S.B., R.O., L.-G.M., and L.B. designed the studies; M.S., L.-G.M., and L.B. wrote the manuscript. All authors have given approval to the final version of the manuscript.

\section{Funding}

The authors thank the Michael J. Fox Foundation for Parkinson's Research, The Netherlands Organization for Scientific Research via Gravity program 024.001.035, ECHO Grants 711011017 and 717014001, and VICI Grant 016150366.

\section{Notes}

The authors declare no competing financial interest.

\section{REFERENCES}

(1) Skerrett, R., Malm, T., and Landreth, G. (2014) Nuclear receptors in neurodegenerative diseases. Neurobiol. Dis. 72, 104-116.

(2) McFarland, K., Spalding, T. A., Hubbard, D., Ma, J.-N., Olsson, R., and Burstein, E. S. (2013) Low dose bexarotene treatment rescues dopamine neurons and restores behavioral function in models of Parkinson's disease. ACS Chem. Neurosci. 4, 1430-1438.

(3) Agarwal, S., Yadav, A., and Chaturvedi, R. K. (2017) Peroxisome proliferator-activated receptors (PPARs) as therapeutic target in neurodegenerative disorders. Biochem. Biophys. Res. Commun. 483, 1166-1177.

(4) Spathis, A. D., Asvos, X., Ziavra, D., Karampelas, T., Topouzis, S., Cournia, Z., Qing, X., Alexakos, P., Smits, L. M., Dalla, C., Rideout, H. J., Schwamborn, J. C., Tamvakopoulos, C., Fokas, D., and Vassilatis, D. K. (2017) NURR1:RXR $\alpha$ heterodimer activation as monotherapy for Parkinson's disease. Proc. Natl. Acad. Sci. U. S. A. 114, 3999-4004.

(5) de Lera, Á. R., Krezel, W., and Rühl, R. (2016) An Endogenous Mammalian Retinoid X Receptor Ligand, At Last! ChemMedChem 11, $1027-1037$.

(6) Bourguet, W., Ruff, M., Chambon, P., Gronemeyer, H., and Moras, D. (1995) Crystal structure of the ligand-binding domain of the human nuclear receptor RXR-alpha. Nature 375, 377-382.

(7) Egea, P. F., Mitschler, A., Rochel, N., Ruff, M., Chambon, P., and Moras, D. (2000) Crystal structure of the human RXRalpha ligandbinding domain bound to its natural ligand: 9-cis retinoic acid. EMBO J. 19, 2592-2601.

(8) Barnard, J. H., Collings, J. C., Whiting, A., Przyborski, S. A., and Marder, T. B. (2009) Synthetic Retinoids: Structure-Activity Relationships. Chem. - Eur. J. 15, 11430-11442.

(9) Dawson, M. I., and Xia, Z. (2012) The retinoid X receptors and their ligands. Biochim. Biophys. Acta, Mol. Cell Biol. Lipids 1821, 21-56.

(10) Vaz, B., and de Lera, Á. R. (2012) Advances in drug design with RXR modulators. Expert Opin. Drug Discovery 7, 1003-1016.

(11) Pérez, E., Bourguet, W., Gronemeyer, H., and de Lera, A. R (2012) Modulation of RXR function through ligand design. Biochim. Biophys. Acta, Mol. Cell Biol. Lipids 1821, 57-69.

(12) Huang, P., Chandra, V., and Rastinejad, F. (2014) Retinoic Acid Actions through Mammalian Nuclear Receptors. Chem. Rev. 114, 233254.

(13) Álvarez, R., Vaz, B., Gronemeyer, H., and de Lera, Á. R. (2014) Functions, Therapeutic Applications, and Synthesis of Retinoids and Carotenoids. Chem. Rev. 114, 1-125.

(14) Burris, T. P., Solt, L. A., Wang, Y., Crumbley, C., Banerjee, S., Griffett, K., Lundasen, T., Hughes, T., and Kojetin, D. J. (2013) Nuclear Receptors and Their Selective Pharmacologic Modulators. Pharmacol. Rev. 65, 710-778.

(15) Lefebvre, P., Benomar, Y., and Staels, B. (2010) Retinoid X receptors: common heterodimerization partners with distinct functions. Trends Endocrinol. Metab. 21, 676-683.

(16) Cramer, P. E., Cirrito, J. R., Wesson, D. W., Lee, C. Y. D., Karlo, J. C., Zinn, A. E., Casali, B. T., Restivo, J. L., Goebel, W. D., James, M. J., Brunden, K. R., Wilson, D. A., and Landreth, G. E. (2012) ApoEDirected Therapeutics Rapidly Clear $\beta$-Amyloid and Reverse Deficits in AD Mouse Models. Science 335, 1503-1506.

(17) Koster, K. P., Smith, C., Valencia-Olvera, A. C., Thatcher, G. R. J., Tai, L. M., and LaDu, M. J. (2017) Rexinoids as therapeutics for Alzheimer' disease: Role of APOE. Curr. Top. Med. Chem. 17, 708720 . 
(18) Michellys, P.-Y., Ardecky, R. J., Chen, J.-H., D’Arrigo, J., Grese, T. A., Karanewsky, D. S., Leibowitz, M. D., Liu, S., Mais, D. A., Mapes, C. M., Montrose-Rafizadeh, C., Ogilvie, K. M., Reifel-Miller, A., Rungta, D., Thompson, A. W., Tyhonas, J. S., and Boehm, M. F. (2003) Design, Synthesis, and Structure-Activity Relationship Studies of Novel 6,7-Locked-[7-(2-alkoxy-3,5-dialkylbenzene)-3-methylocta]2,4,6-trienoic Acids. J. Med. Chem. 46, 4087-4103.

(19) Leibowitz, M. D., Ardecky, R. J., Boehm, M. F., Broderick, C. L., Carfagna, M. A., Crombie, D. L., D’Arrigo, J., Etgen, G. J., Faul, M. M., Grese, T. A., Havel, H., Hein, N. I., Heyman, R. A., Jolley, D., Klausing, K., Liu, S., Mais, D. E., Mapes, C. M., Marschke, K. B., Michellys, P.-Y., Montrose-Rafizadeh, C., Ogilvie, K. M., Pascual, B., Rungta, D., Tyhonas, J. S., Urcan, M. S., Wardlow, M., Yumibe, N., and ReifelMiller, A. (2006) Biological characterization of a heterodimer-selective retinoid $\mathrm{X}$ receptor modulator: potential benefits for the treatment of type 2 diabetes. Endocrinology 147, 1044-1053.

(20) Wallén, A., Zetterström, R. H., Solomin, L., Arvidsson, M., Olson, L., and Perlmann, T. (1999) Fate of mesencephalic AHD2expressing dopamine progenitor cells in NURR1 mutant mice. Exp. Cell Res. 253, 737-746.

(21) Jankovic, J., Chen, S., and Le, W. D. (2005) The role of NURR1 in the development of dopaminergic neurons and Parkinson's disease. Prog. Neurobiol. 77, 128-138.

(22) Decressac, M., Volakakis, N., Björklund, A., and Perlmann, T. (2013) NURR1 in Parkinson disease-from pathogenesis to therapeutic potential. Nat. Rev. Neurol. 9, 629-636.

(23) Zetterström, R. H. (1997) Dopamine Neuron Agenesis in NURR1-Deficient Mice. Science 276, 248-250.

(24) Saijo, K., Winner, B., Carson, C. T., Collier, J. G., Boyer, L., Rosenfeld, M. G., Gage, F. H., and Glass, C. K. (2009) A NURR1/ CoREST Pathway in Microglia and Astrocytes Protects Dopaminergic Neurons from Inflammation-Induced Death. Cell 137, 47-59.

(25) Le, W.-D., Xu, P., Jankovic, J., Jiang, H., Appel, S. H., Smith, R. G., and Vassilatis, D. K. (2003) Mutations in NR4A2 associated with familial Parkinson disease. Nat. Genet. 33, 85-89.

(26) Sleiman, P. M. A., Healy, D. G., Muqit, M. M. K., Yang, Y. X., Van Der Brug, M., Holton, J. L., Revesz, T., Quinn, N. P., Bhatia, K., Diss, J. K. J., Lees, A. J., Cookson, M. R., Latchman, D. S., and Wood, N. W. (2009) Characterisation of a novel NR4A2 mutation in Parkinson's disease brain. Neurosci. Lett. 457, 75-79.

(27) Wang, Z., Benoit, G., Liu, J., Prasad, S., Aarnisalo, P., Liu, X., Xu, H., Walker, N. P. C., and Perlmann, T. (2003) Structure and function of NURR1 identifies a class of ligand-independent nuclear receptors. Nature 423, 555-560.

(28) Tice, C. M., and Zheng, Y.-J. (2016) Non-canonical modulators of nuclear receptors. Bioorg. Med. Chem. Lett. 26, 4157-4164.

(29) Friling, S., Bergsland, M., and Kjellander, S. (2009) Activation of Retinoid X Receptor increases dopamine cell survival in models for Parkinson's disease. BMC Neurosci. 10, 146.

(30) Wang, J., Bi, W., Zhao, W., Varghese, M., Koch, R. J., Walker, R. H., Chandraratna, R. A., Sanders, M. E., Janesick, A., Blumberg, B., Ward, L., Ho, L., and Pasinetti, G. M. (2016) Selective brain penetrable NURR1 transactivator for treating Parkinson's disease. Oncotarget 7, 7469-7479.

(31) Giner, X. C., Cotnoir-White, D., Mader, S., and Levesque, D. (2015) Selective ligand activity at Nur/retinoid X receptor complexes revealed by dimer-specific bioluminescence resonance energy transferbased sensors. FASEB J. 29, 4256-4267.

(32) Morita, K., Kawana, K., Sodeyama, M., Shimomura, I., Kagechika, H., and Makishima, M. (2005) Selective allosteric ligand activation of the retinoid X receptor heterodimers of NGFI-B and NURR1. Biochem. Pharmacol. 71, 98-107.

(33) Sundén, H., Schäfer, A., Scheepstra, M., Leysen, S., Malo, M., Ma, J.-N., Burstein, E. S., Ottmann, C., Brunsveld, L., and Olsson, R. (2016) Chiral Dihydrobenzofuran Acids Show Potent Retinoid X Receptor-Nuclear Receptor Related 1 Protein Dimer Activation. J. Med. Chem. 59, 1232-1238.
(34) Rodrigues, T., Reker, D., Schneider, P., and Schneider, G. (2016) Counting on natural products for drug design. Nat. Chem. 8, $531-541$.

(35) Scheepstra, M., Nieto, L., Hirsch, A. K. H., Fuchs, S., Leysen, S., Lam, C. V., in het Panhuis, L., van Boeckel, C. A. A., Wienk, H., Boelens, R., Ottmann, C., Milroy, L.-G., and Brunsveld, L. (2014) A Natural-Product Switch for a Dynamic Protein Interface. Angew. Chem., Int. Ed. 53, 6443-6448.

(36) Nahoum, V., Perez, E., Germain, P., Rodriguez-Barrios, F., Manzo, F., Kammerer, S., Lemaire, G., Hirsch, O., Royer, C. A., Gronemeyer, H., de Lera, A. R., and Bourguet, W. (2007) Modulators of the structural dynamics of the retinoid $\mathrm{X}$ receptor to reveal receptor function. Proc. Natl. Acad. Sci. U. S. A. 104, 17323-17328.

(37) Billingsley, K. L., Barder, T. E., and Buchwald, S. L. (2007) Palladium-catalyzed borylation of aryl chlorides: scope, applications, and computational studies. Angew. Chem., Int. Ed. 46, 5359-5363.

(38) Takahashi, B., Ohta, K., Kawachi, E., Fukasawa, H., Hashimoto, Y., and Kagechika, H. (2002) Novel Retinoid X Receptor Antagonists: Specific Inhibition of Retinoid Synergism in RXR-RAR Heterodimer Actions. J. Med. Chem. 45, 3327-3330.

(39) Gunther, J. R., Parent, A. A., and Katzenellenbogen, J. A. (2009) Alternative inhibition of androgen receptor signaling: peptidomimetic pyrimidines as direct androgen receptor/coactivator disruptors. ACS Chem. Biol. 4, 435-440.

(40) LaFrate, A. L., Gunther, J. R., Carlson, K. E., and Katzenellenbogen, J. A. (2008) Synthesis and biological evaluation of guanylhydrazone coactivator binding inhibitors for the estrogen receptor. Bioorg. Med. Chem. 16, 10075-10084.

(41) Tan, P. K., Wang, J., Littler, P.-L. H., Wong, K. K., Sweetnam, T. A., Keefe, W., Nash, N. R., Reding, E. C., Piu, F., Brann, M. R., and Schiffer, H. H. (2007) Monitoring interactions between receptor tyrosine kinases and their downstream effector proteins in living cells using bioluminescence resonance energy transfer. Mol. Pharmacol. 72, $1440-1446$.

(42) Ohsawa, F., Morishita, K.-I., Yamada, S., Makishima, M., and Kakuta, H. (2010) Modification at the Lipophilic Domain of RXR Agonists Differentially Influences Activation of RXR Heterodimers. ACS Med. Chem. Lett. 1, 521-525.

(43) Kawata, K., Morishita, K., Nakayama, M., Yamada, S., Kobayashi, T., Furusawa, Y., Arimoto-Kobayashi, S., Oohashi, T., Makishima, M., Naitou, H., Ishitsubo, E., Tokiwa, H., Tai, A., and Kakuta, H. (2015) RXR partial agonist produced by side chain repositioning of alkoxy RXR full agonist retains antitype 2 diabetes activity without the adverse effects. J. Med. Chem. 58, 912-926.

(44) Kojetin, D. J., Matta-Camacho, E., Hughes, T. S., Srinivasan, S., Nwachukwu, J. C., Cavett, V., Nowak, J., Chalmers, M. J., Marciano, D. P., Kamenecka, T. M., Shulman, A. I., Rance, M., Griffin, P. R., Bruning, J. B., and Nettles, K. W. (2015) Structural mechanism for signal transduction in RXR nuclear receptor heterodimers. Nat. Commun. 6, 8013.

(45) Gampe, R. T., Montana, V. G., Lambert, M. H., Miller, A. B., Bledsoe, R. K., Milburn, M. V., Kliewer, S. A., Willson, T. M., and Xu, H. E. (2000) Asymmetry in the PPARgamma/RXRalpha crystal structure reveals the molecular basis of heterodimerization among nuclear receptors. Mol. Cell 5, 545-555.

(46) Flaig, R, Greschik, H., Peluso-Iltis, C., and Moras, D. (2005) Structural Basis for the Cell-specific Activities of the NGFI-B and the NURR1 Ligand-binding Domain. J. Biol. Chem. 280, 19250-19258.

(47) Chandra, V., Huang, P., Hamuro, Y., Raghuram, S., Wang, Y., Burris, T. P., and Rastinejad, F. (2008) Structure of the intact PPARgamma-RXR- nuclear receptor complex on DNA. Nature 456, 350356.

(48) Ito, M., Fukuzawa, K., Mochizuki, Y., Nakano, T., and Tanaka, S. (2007) Ab initio fragment molecular orbital study of molecular interactions between liganded retinoid $\mathrm{X}$ receptor and its coactivator: roles of helix 12 in the coactivator binding mechanism. J. Phys. Chem. B $111,3525-3533$. 